\title{
EVALUASI PERBANDINGAN KINERJA KEUANGAN PERUSAHAAN BERDASARKAN METODE FINANCIAL RATIO DAN DU PONT SYSTEM PADA PT. ANGKASA PURA I DAN PT. ANGKASA PURA II (PERIODE 2013-2016)
}

\author{
Iriani Tukwain dan Saur Costanius Simamora \\ Mahasiswa Fakultas Ekonomi dan Dosen Tetap Manajemen Unsurya \\ Iriani tukwain@yahoo.com dan saurcsimamora@gmail.com
}

\begin{abstract}
ABSTRAK
Tujuan dari penelitian ini adalah mengetahui kinerja keuangan pada PT. Angkasa Pura I dan PT. Angkasa Pura II periode 2013-2016 dengan menggunakan analisis financial ratio (rasio keuangan) dan Du Pont System secara time series. Berdasarkan hasil analisis rasio keuangan, meliputi perhitungan rasio likuiditas, solvabilitas, aktivitas, dan profitabilitas menunjukkan bahwa kinerja keuangan kedua perusahaan dalam kondisi baik meskipun berfluktuasi. Hasil kinerja keuangan perusahaan yang cenderung meningkat serta diatas rata-rata industri pada PT. Angkasa Pura I ada pada hasil rasio solvabilitas sedangkan pada PT. Angkasa Pura II hasil rasio profitabilitas, rasio likuditas dan aktivitas menunjukkan hasil baik namun lebih unggul dari PT. Angkasa pura I. Berdasarkan hasil Du Pont System, perkembangan tingkat kinerja perusahaan keuangan dilihat dari pencapaian ROE yang meningkat setiap tahun yang sebagian besar dipengaruhi oleh tingkat ROI (hasil dari perhitungan NPM dan TATO) serta adanya unsur leverage. Perhitungan uji beda independent t-tes menunjukkan hasil 0,03 dimana menjawab hipotesis bahwa kedua perusahaan maka terdapat perbedaan yang signifikan antara hasil metode finnacial ratio dan $d u$ pont system. Maka dapat disimpulkan bahwa kondisi kinerja keuangan kedua perusahaan dalam kondisi baik. Namun hasil analisis yang dilihat dari kedua metode menunjukkan bahwa pada PT. Angkasa Pura II lebih unggul.
\end{abstract}

Kata kunci: Perbandingan, rasio keuangan, du pont system, analisis time series, Angkasa Pura I, Angkasa Pura II, evaluasi perbandingan, kinerja keuangan, BUMN.

\section{PENDAHULUAN}

\section{Latar Belakang Masalah}

Menurut UUD No.19 Tahun 2003, Badan Usaha Milik Negara (BUMN) adalah badan usaha yang seluruh atau sebagian besar modalnya dimiliki oleh negara melalui penyertaan secara langsung yang berasal dari kekayaan negara yang dipisahkan. BUMN merupakan pelaku usaha dominan disemua bidang yang dibentuk pemerintah sebagai pengerakan utama pertumbuhan ekonomi nasional dan diharapkan dapat memberikan deviden atau membagi laba kepada negara selaku pemegang saham sebagai penerimaan Negara Bukan Pajak (PNBP) dalam Anggaran Pendapatan dan Negara (APBN) dengan menerapkan deviden pay out ratio.

Berdirinya Angkasa Pura bertujuan untuk menjalankan pengelolaan dan pengusahaan dalam bidang jasa kebandarudaraan dan jasa terkait bandar 
udara dengan mengoptimalkan pemberdayaan potensi sumber daya yang dimiliki dan menerapkan tata kelola perusahaan yang baik. Hal tersebut dilakukan agar perusahaan dapat menghasilkan layanan jasa yang bermutu tinggi dan berdaya saing kuat sehingga dapat meningkatkan nilai perusahaan dan kepercayaan masyarakat. Semakin berkembangnya industri penerbangan nasional dan internasional, bandara sebagai penyedia jasa penerbangan harus mampu melakukan pengembangan dan pengelolaan dengan cara terus memodernisasi sistem, peralatan, infrastruktur dan penerapan teknologi yang lebih memadai demi mengoptimalisasi pelayanan bagi pengguna jasa.

Perkembangan teknologi yang semakin canggih membuat perusahaan harus mampu menciptakan nilai bagi perusahaan tersebut. Persaingan bisnis diberbagai sektor terutama di area kebandarudaraan akan membuat manajemen perusahaan harus mampu mengatur strategi-strategi yang baru agar perusahaan dapat bertahan menjalankan bisnisnya.

Kondisi ini menyebabkan banyak perkembangan pemikiran dan peran pada segala bidang usaha. Berbagai macam bentuk kebijakan dan pengawasan telah dilakukan dalam rangka mempermudah pencapaian tujuan perusahaan dengan sebuah bentuk informasi yang tepat dan akurat sebagai media dalam pengambilan keputusan. Bentuk informasi tersebut yaitu mengenai pengukuran kinerja perusahaan yang tercermin dalam laporan keuangan. Cara umum yang biasanya digunakan untuk menilai dan mengukur kinerja perusahaan adalah dengan analisis rasio keuangan yang meliputi rasio likuiditas, aktivitas, solvabilitas dan profitabilitas. Menggunakan analisis rasio keuangan ini dapat menilai baik buruknya keadaan atau posisi keuangan perusahaan. Namun manajemen juga perlu mengetahui sebab akibat dari hasil kinerja perusahaan secara detail dan terstruktur dengan penggunaan analisis du pont system.

Kinerja keuangan suatu perusahaan dapat diartikan sebagai prospek atau masa depan, pertumbuhan dan potensi perkembangan yang baik bagi perusahaan. Informasi kinerja keuangan diperlukan untuk menilai perubahan potensial sumber daya ekonomi, yang mungkin dikendalikan di masa depan dan untuk memprediksi kapasitas produksi dari sumber daya yang ada, Untuk memberi kepercayaan pada investor, tentunya pihak 
perusahaan harus memberikan rincian laporan keuangan sebagai penilaian kinerja keuangan perusahaan yang selama ini dijalankan. Kondisi keuangan perusahaan dapat diketahui dari laporan keuangan perusahaan yang bersangkutan, yang terdiri dari neraca, laporan laba rugi serta laporan-laporan keuangan yang lain. Hasil analisis laporan keuangan akan membantu menginterpretasikan berbagai hubungan kunci serta kecenderungan yang dapat memberikan dasar pertimbangan mengenai potensi keberhasilan perusahaan di masa yang akan datang.

$$
\text { Perkembangan Industri }
$$

dibidang jasa kebandarudaraan ini ikut meningkatkan pula minat para investor dan calon investor untuk berinvestasi pada industri tersebut. Industri ini memiliki peluang dan prospek yang cerah dimasa mendatang mengingat tingginya jumlah pengguna jasa kebandarudaraan yang mecapai lima juta penumpang domestik maupun internasional tahun 2015. Dari laporan keuangan diperoleh bahwa PT. Angkasa Pura I dan PT. Angkasa Pura II merupakan perusahaan yang besar membuat INACA (Indonesia National Carriers Air Association) menawarkan jadwal terbang malam pada beberapa bandara yang dikelola kedua perusahaan namun kesiapan infrastruktur bandara dibeberapa kota yang masih terbatas. Karena itu, penawaran kepada investor baik domestik maupun asing untuk turut serta mengelola bandara bisa menjadi solusi tepat saat kedua perusahaan kewalahan mengatasi perkembangan angkutan udara yang begitu pesat.

Melihat gejala ini, tentunya para investor akan semakin tertarik untuk berbisnis dan berinvestasi pada industri ini. Akan tetapi, ketidakpastian dalam berinvestasi mendorong investor untuk berhati-hati dalam mengambil keputusan yang dapat memaksimalkan return yang dikombinasikan dengan resiko tentu dalam setiap keputusan investasinya. Salah satu aspek penting yang perlu diperhatikan dalam melakukan strategi investasi yaitu dengan melihat kinerja keuangan perusahaan. Berdasarkan penjelasan inilah, peneliti tertarik untuk menganalisa atau mengevaluasi bagaimana kinerja keuangan perusahaan serta melakukan perbandingan kinerja keuangan dari metode financial ratio dan $d u$ pont system dengan ini analisis tersebut guna diketahui manakah perusahaan yang kinerja keuangannya lebih baik sehingga dapat mengambil langkah atau tindakan untuk meningkatkan dan mengembangkan perusahaan kedepan. 


\section{Batasan Masalah}

Mengingat masih adanya berbagai keterbatasan dan menghindari meluaskan permasalahan. Oleh karena itu, permasalahan yang akan dikaji dalam penelitian ini dibatasi pada :

1. Data laporan keuangan perusahaan yang dianalisis periode 2013-2016.

2. Metode yang digunakan adalah financial ratio dan $d u$ pont system.

3. Perusahaan yang dibahas hanya perusahaan manajemen kebandarudaraan yang data keuangannya go publik yang diantaranya PT. Angkasa Pura I dan PT. Angkasa Pura II.

4. Perusahaan yang dibahas hanya pada induk perusahaan bukan induk dan entitas anak perusahaan.

\section{Rumusan Masalah}

Berdasarkan latar belakang penelitian yang dikemukakan, maka rumusan masalah yang akan diteliti dalam penelitian ini adalah :

1. Bagaimana perkembangan kinerja keuangan pada PT. Angkasa Pura I dan PT. Angkasa Pura II jika dilihat dari metode Financial Ratio periode 2013-2016?
2. Bagaimana perkembangan kinerja keuangan pada PT. Angkasa Pura I dan PT. Angkasa Pura II jika dilihat dari metode Du Pont System periode 2013-2016?

3. Bagimana perbandingan kinerja keuangan pada PT. Angkasa Pura I dan PT. Angkasa Pura II jika dilihat dari metode Financial Ratio dan Du Pont System periode 2013-2016?

\section{TINJAUAN PUSTAKA}

\section{Landasan Teori}

a. Pengertian Badan Usaha Milik Negara (BUMN)

Menurut UU No. 19 tahun 2003 (pasal 1), Badan Usaha Milik Negara yang selanjutnya disebut BUMN adalah badan usaha yang seluruh atau sebagian besar modalnya dimiliki oleh negara melalui penyertaan secara langsung yang berasal dari kekayaan negara yang dipisahkan.

b. Tujuan dan Manfaat Badan Usaha

\section{Milik Negara (BUMN)}

Dibentuknya BUMN memiliki maksud dan tujuan (UU No. 19 Pasal 2) sebagai berikut :

1) Memberikan sumbangan bagi perkembangan perekonomian nasional pada umumnya dan 
penerimaan negara pada

khususnya,

2) Mengejar keuntungan,

3) Menyelenggarakan kemanfaatan umum berupa penyediaan barang dan/atau jasa yang bermutu tinggi dan memadai bagi pemenuhan hajat hidup orang banyak,

4) Menjadi perintis kegiatan-kegiatan usaha yang belum dapat dilaksanakan oleh sektor swasta dan koperasi,

5) Turut aktif memberikan bimbingan dan bantuan kepada pengusaha golongan ekonomi lemah, koperasi, dan masyarakat.

\section{Laporan Keuangan}

\section{a. Pengertian Laporan Keuangan}

Pengertian laporan keuangan menurut IAI (dalam PSAK no. 1, 2009) adalah suatu penyajian terstruktur dari posisi keuangan dan kinerja keuangan suatu perusahan. Laporan keuangan juga menunjukkan hasil pertanggungjawaban manajemen atas penggunakaan sumber daya yang dipercayakan kepada mereka.

Menurut Bambang Hermanto (2015:1), laporan keuangan atau disebut dengan Financial statement berisikan informasi tentang prestasi perusahaan dimasa lampau dan dapat memberikan petunjuk untuk menetapkan kebijakan dimasa yang akan datang.

Menurut Harahap (2015:105) laporan keuangan menggambarkan kondisi keuangan dan hasil usaha suatu perusahaan pada saat tertentu atau jangka waktu tertentu. Bagi para analis, laporan keuangan merupakan media yang paling penting untuk menilai prestasi dan kondisi ekonomis suatu perusahaan.

b. Tujuan dan Manfaat Laporan Keuangan

Menurut IAI (2012:9), tujuan laporan keuangan adalah menyedia informasi mengenai posisi keuangan, kinerja, dan perubahan posisi keuangan suatu perusahaan yang bermanfaat bagi sejumlah besar pengguna dalam pengambilan keputusan ekonomi.

Menurut Kasmir (2012:10), berikut beberapa tujuan dan manfaat pada laporan keuangan :

a) Memberikan informasi tentang jenis dan jumlah aktiva (harta) yang dimiliki perusahaan saat ini,

b) Memberikan informasi tentang jenis dan jumlah kewajiban dan modal yang dimiliki perusahaan saat ini,

c) Memberikan informasi tentang jumlah biaya dan jenis biayayang diperoleh pada suatu periode tertentu, 
d) Memberikan informasi tentang jumlah biaya dan jenis biaya yang dikeluarkan perusahaan dalam suatu periode tertentu,

e) Memberikan informasi tentang perubahan-perubahan yang terjadi seperti aktiva, pasiva dan modal perusahaan,

f) Memberikan informasi tentang kinerja manajemen perusahaan dalam suatu periode,

g) Memberikan informasi tentang kinerja catatan-catatan atas laporan keuangan,

h) Informasi keuangan lainnya.

\section{c. Unsur-unsur Laporan Keuangan}

Menurut IAI (2012:11), mengidentifikasi unsur-unsur sebagai berikut :

\section{a) Aset}

Aset didefinisikan sebagai sumber daya yang dikuasai oleh sebuah perusahaan sebagai hasil dari peristiwa lampau dan diharapkan mengalirkan keuntungan di masa mendatang bagi perusahaan tersebut.

\section{b) Liabilitas}

Liabilitas didefinisikan sebagai kewajiban yang dimiliki sebuah perusahaan di masa kini sebagai hasil dari periistiwa lampau, yang penyelesaiannya diharapkan dihasilkan dari aliran keluar sumber daya yang merupakan keuntungan ekonomi bagi perusahaan tersebut.

\section{c) Ekuitas}

Ekuitas didefinisikan sebagai laba sisa pada aset-aset sebuah perusahaan setelah dikurangi semua liabilitasnya.

\section{d. Jenis Laporan Keuangan}

Dalam praktiknya, secara umum ada lima macam jenis laporan keuangan yang biasa disusun yaitu :

\section{Neraca (balance sheet)}

Neraca merupakan laporan yang menunjukkan posisi keuangan perusahaan pada tanggal tertentu. Artinya posisi jumlah dan jenis aktiva (harta) dan pasiva (kewajiban dan ekuitas) suatu perusahaan penyusunan komponen di dalam neraca berdasarkan pada tingkat likuiditas dan jatuh tempo. Artinya penyusunan komponen neraca harus didasarkan likuiditasnya atau komponen yang paling mudah dicairkan. Kasmir (2012:28).

Menurut Bambang Hermanto (2015:11) Neraca adalah laporan keuangan yang menunujukkan tentang Aktiva, kewajiban (Hutang) dan Modal dari suatu perusahaan pada waktu tertentu. Jadi neraca dapat menunjukkan posisi laporan keuangan kepada semua pihak tentang jumlah harta (Aktiva) kewajiban dan modal yang dimiliki oleh perusahaan pada tanggal tertentu. 


\section{Laporan Laba Rugi (income statement)}

Menurut Kasmir

(2012:29)

Laporan laba rugi merupakan laporan keuangan yang menggambarkan hasil usaha perusahaan dalam suatu periode tertentu. Dalam laporan laba rugi ini tergambar jumlah pendapat dan sumbersumber pendapat yang diperoleh. Kemudian, juga tergambar jumlah biaya dan jenis-jenis biaya yang dikeluarkan selama periode tertentu. Dari jumlah pendapatan dan jumlah biaya ini terdapat selisih yang disebut laba atau rugi. Jika jumlah pendapatan lebih besar dari jumlah biaya, perusahaan dikatakan laba. Sebaliknya jika jumlah pendapatan lebih kecil dari jumlah biaya perusahaan dikatakan rugi.

Menurut Bambang Hermanto (2015:24) Laporan laba rugi adalah sebuah laporan yang isinya melaporkan tentang hasil usaha selama satu periode dengan menunjukan beberapa jumlah biaya yang digunakan untuk memperoleh hasil usaha tersebut. Selisih antara hasil usaha dengan biaya yang digunakan merupakan laba yang diperoleh jika hasil usaha lebih besar dari jumlah biaya, apabila hasil usaha lebih kecil dibandingkan dengan biaya maka perusahaan akan menderita kerugian, laporan dimana semua lebih mencerminkan kegiatan usaha perusahaan selama satu periode, dimana semua kegiatan akan memberikan kontribusi berupa hasil usaha, sehingga kemajuan-kemajuan yang dicapai perusahaan dalam setiap periode dapat diketahui hasilnya.

\section{Laporan Perubahan Modal}

Menurut Kasmir (2012:29) Laporan perubahan modal merupakan laporan yang berisi jumlah dan jenis modal yang dimiliki pada saat ini. Kemudian, laporan ini juga menjelaskan perubahan modal dan sebab-sebab terjadinya perubahan modal di perusahaan. Laporan perubahan modal jarang dibuat bila tidak terjadi perubahan modal. Artinya laporan ini baru dibuat bila memang ada perubahan modal.

Menurut Bambang Hermanto (2015:28) Laporan perubahan modal dibuat guna melengkapi laporan sebelumnya yaitu neraca atau perhitungan laba rugi, dalam laporan perubahan modal berisikan sebab-sebab terjadinya perubahan modal perusahaan. Pada perusahaan perseroan perubahan modal ditunjukan dalam laporan laba yang ditahan (Retained Earning Statement) atau dapat disebut laporan perubahan modal. Di dalam laporan ini ditunjukkan laba tidak dibagi awal 
tahun, ditambah dengan laba bersih setelah pajak yang diperoleh periode sekarang dikurangi dengan hak pemegang saham berupa deviden dan sisanya merupakan laba ditahan pada akhir tahun.

\section{Laporan Arus Kas}

Menurut Kasmir

(2012:29)

Laporan arus kas merupakan laporan yang menunjukkan semua aspek yang berkaitan dengan kegiatan perusahaan, baik yang berpengaruh lansung atau tidak langsung terhadap kas. Laporan arus kas harus disusun berdasarkan konsep kas selama periode laporan. Laporan kas terdiri arus kas masuk (cash in)dan arus kas keluar (cash out) selama periode tertetu. Kas masuk terdiri uang yang masuk ke perusahaan, seperti hasil penjualan atau penerimaan lainnya, sedangkan kas keluar merupakan sejumlah pengeluaran biaya operasional perusahaan.

Menurut Bambang Hermanto (2015:2) Laporan arus kas adalah suatu ikhtisar penerimaan dan pengeluaran kas untuk periode waktu tertentu, adapun laporan arus kas (ikhtisar penerimaan atau pengeluaran kas) terbagi dalam tiga bagian yaitu :
a) Kegiatan Operasional
b) Kegiatan Investasi
c) Kegiatan Keuangan.

\section{Laporan Catatan Atas Laporan} Keuangan

Menurut Kasmir

(2012:30)

Laporan catatan atas laporan keuangan merupakan laporan yang memberikan informasi apabila ada laporan keuangan yang merupakan penjelasan tertentu. Artinya terkadang ada komponen atau nilai dalam laporan keuangan yang perlu diberi penjelasan terlebih dulu sehingga jelas. Hal ini perlu dilakukan agar pihak-pihak yang tidak salah dalam penafsirannya.

Menurut Bambang Hermanto (2015:2) Laporan catatan atas laporan keuangan tersusun atas fakta yang dicatat sesuai prinsip akuntansi dari pertimbangan akuntansi. Fakta yang dicatat adalah fakta-fakta atau kejadiankejadian usaha.

\section{Analisis Laporan Keuangan}

\section{a. Pengertian Analisis Laporan}

\section{Keuangan}

Menurut Kasmir (2012:66) dengan analisis laporan keuangan dapat mengetahui posisi keuangan, setelah dilakukan analisis laporan keuangan secara mendalam, akan terlihat apakah perusahaan dapat mencapai target yang telah direncanakan sebelumnya atau tidak.

Menurut Sofyan S. Harahap (2015:189) Analisis laporan keuangan 
adalah menguraikan pos-pos laporan keuangan menjadi unit informasi yang lebih kecil dan melihat hubungannya yang bersifat signifikan atau yang mempunyai makna antara satu dengan yang lain baik antara dua kuantitatif maupun data non-kuantitatif dengan tujuan untuk mengetahui kondisi keuangan lebih dalam yang sangat penting dalam proses menghasilkan keputusan.

\section{b. Tujuan dan Manfaat Analisis} Laporan Keuangan

Menurut Kasmir (2012:68), secara umum dikatakan bahwa tujuan dan manfaat analisis laporan keuangan.

1. Untuk mengetahui posisi keuangan perusahaan dalam satu periode tertentu, baik harta, kewajiban, modal, maupun hasil usaha yang telah dicapai untuk beberapa periode;

2. Untuk mengetahui kelemahankelemahan apa saja yeng menjadi kekurangan perusahaan;

3. Untuk mengetahui kekuatankekuatan yang dimiliki;

4. Untuk mengetahui langkahlangkah perbaikan apa saja yang perlu dilakukan kedepan yang berkaitan didengan posisi keuangan perusahaan saat ini;
5. Untuk melakukan penilaian menajemen ke depan apakah perlu penyegaran atau tidak karena sudah dianggap berhasil atau gagal;

6. Dapat juga digunakan sebagai pembanding dengan perusahaan sejenis tentang hasil yang mereka capai.

\section{c. Jenis Teknik Analisis Laporan}

\section{Keuangan}

Di samping metode yang digunakan untuk menganalisis laporan keuangan ada beberapa jenis teknik analisis laporan keuangan, diantaranya sebagai berikut :

\section{1) Analisis perbandingan antara laporan keuangan}

Kasmir (2012:72), Analisis perbandingan laporan keuangan dapat dilakukan dengan dua model, yaitu analisis horizontal atau analisis dinamis dan analisis vertikal atau analisis statis. Dalam analisis horizontal yang dibandingkan adalh laporan keuangan untuk bebrapan periode, sedangkan analisis vertikal adalah jika kita hanya membandingkan satu pos dengan pos lain dalam satu laporan keuangan dan hanya meliputi satu periode laporan keuangan. Ada beberapa keuntungan jika dilihat dari analisis horizontal dibandingkan dengan analsisi vertikal. 
Dalam analsisi horizontal, kita akan tau terjadinya perubahan-perubahan terhadap komponen laporan keuangan dari satu periode ke periode lain. Seperti misalnya kenaikan atau penurunan komponen-komponen yang ada di laporan keuangan. Sementara itu dalam analisis tatis hal tersebut tidak terlihat. Dari analisis ini akan dapat diketahui perubahan-perubahan yang akan terjadi. Perubahan yang terjadi dapat berupa kenaikan atau penurunan dari masingmasing kemajuan atau kegagalan dalam mencapai target yang telah ditetapkan sebelumnya. Secara umum dari hasil analisis ini akan terlihat antara lain :

a) Angka-angka dalam rupiah,

b) Angka-angka dalam persentase,

c) Kenaikan atau penurunan jumlah rupiah,

d) Kenaikan atau penurunan baik dalam rupiah maupun dalam persentase.

\section{2) Analisis persentase per komponen}

Analisis persentase per komponen merupakan analisis yang dilakukan untuk membandingkan antara komponen yang ada dalam suatu laporan keuangan, baik yang ada di neraca maupun laporan laba rugi. Analisis ini dilakukan untuk mengetahui
a) Persentase investasi terhadap masing-masing aktiva atau terhadap total aktiva,
b) Struktur permodalan,
c) Komposisi biaya terhadap penjualan.

Analisis ini dilakukan dengan membandingkan setiap perubahaan dalam pos-pos dengan total aktiva atau total pasiva atau total penjualan. Dengan demikian, akan terlihat suatu kenaikan atau penurunan apakah akan menjadi berarti atau memiliki makna tertentu.

\section{3) Analisis rasio}

Analisis Rasio Merupakan analisis yang digunakan untuk mengetahui hubungan pos-pos yang ada dalam satu laporan keuangan atau pos-pos antara laporan keuangan neraca dan laporan laba rugi.

\section{Rasio Keuangan (Financial Ratio)}

\section{a. Pengertian Rasio Keuangan}

Menurut Sofyan S. Harahap (2015:297) Rasio keuangan adalah angka yang diperoleh dari hasil perbandingan dari satu pos laporan keuangan dengan pos lainnya yang mempunyai hubungan yang relevan dan signifikan (berarti). Misalnya antara hutang dan modal, antara kas dan total aset, antara harga pokok produksi dengan total penjualan, da sebagainya. 


\section{b. Tujuan dan Manfaat Rasio} Keuangan

Analisis Rasio keuangan digunakan untuk melihat prospek dan resiko perusahaan pada masa yang mendatang. Faktor prospek dalam rasio tersebut akan mempengaruhi harapan investor terhadapat perusahaan pada masa-masa mendatang (hanafi, 2013:75).

\section{c. Jenis-jenis Rasio Keuangan}

Jenis-jenis rasio keuangan yang dapat digunakan untuk menilai kinerja manajemen beragam. Penggunaan masing-masing rasio tergantung kebutuhan perusahaan, artinya terkadang tidak semua rasio digunakan seperti halnya perusahaan yang bergerak di bidang manfaktur berbeda dengan perusahaan jasa. Jenis - jenis rasio keuangan, yaitu (Kasmir, 2010 : 110) :

\section{Rasio Likuditas}

Harahap (2015:301) Rasio likuiditas menggambarkan kemampuan perusahaan untuk menyelesaikan kewajiban jangka pendeknya. Rasiorasio ini dapat dihitung melalui sumber informasi tentang modal kerja yaitu pospos aktiva lancar dan hutang lancar. Tujuan dan manfaat rasio likuiditas menurut Kasmir (2012:145) yaitu :

a. Untuk mengukur kemampuan perusahaan membayar kewajiban jangka pendek, b. Untuk mengukur kemampuan perusahaan membayar kewajiban jangka pendek tanpa memperhitungkan seddiaan,

c. Untuk mengukur dan membandingkan antara jumlah sediaan yang ada dengan modal kerja perusahaan,

d. Untuk mengukur seberapa besar uang kas yang tersedia untuk membayar hutang,

e. Untuk mengukur seberapa besar perputaran kas,

f. Sebagai alat perencanaan kedepan, terutama yang berkaitan dengan perencanaan kas dan hutang,

g. Menjadi alat pemicu bagi pihak menajemen untuk memperbaiki kinerjanya.

h. Sebagai alat bagi pihak luar terutama yang berkepentingan terhadap perusahaan dalam menilai kemampuan perusahaan agar dapat meningkatkan saling percaya.

Jenis-jenis Rasio likuiditas menurut Kasmir (2012:145) adalah sebagai berikut:

\section{a. Rasio Lancar (Current Ratio)}

Kasmir (2012:134) Rasio Lancar atau (Current Ratio) merupakan rasio untuk mengukur kemampuan perusahaan dalam membayar kewajiban jangka pendek atau hutang yang segera jatuh tempo. 
Harahap (2015:301) Current Ratio atau biasa disebut rasio lancar adalah hasil pembagian antara jumlah aktiva lancar dibagi hutang lancar yang artinya tingkat keamana bagi kreditor jangka pendek.

\section{b. Rasio Cepat (Quick Ratio)}

Harahap (2015:302) rasio ini menunjukkan kemampuan aktiva lancar yang paling likuid mampu menutupi utang lancar. Semakin besar rasio ini semakin baik. Rasio ini juga disebut juga acid test ratio.

\section{c. Rasio Kas (Cash Ratio)}

Bambang (2015:107) cash rasio adalah merupakan rasio yang paling likuid diantara rasio-rasio yang ada, sebab rasio ini hanya memperbandingkan pos-pos lancar yang terdapat dalam aktiva lancar yaitu cash on hand, cash in back dan effek, yang dibandingkan dengan jumlah utang lancar.

\section{Rasio Solvabilitas}

Harahap (2015:303) Rasio Solvabilitas menggunakna kemampuan perusahaan dalam membayar kewajiban jangka panjangnya atau kewajibankewajiban apabila perusahaan dilikuidasi. Rasio ini dapat dihitung dari pos-pos yang sifatnya jangka panjang seperti aktiva tetap dan utang jangka panjang. Tujuan dan mnafaat rasio solvabilitas menurut kasmir (2015:153) diantaranya ialah :

a) untuk mengetahui posisi keuangan terdahap kewajiban kepada pihak lainnya (keditor),

b) Untuk menilai kemmapuan perusahaan dalam memenuhi kewajiban yang bersifat tetap (seperti angsuran pinjaman termasuk bunga),

c) Untuk menilai keseimbangan diantara nilai aktiva khususnya aktiva tetap dengan modal,

d) Untuk menilai seberapa besar aktiva perusahaan dibiayai oleh utang,

e) Untuk menilai seberapa besar pengaruh untang perusahaan terhadap pengelolaan aktiva,

f) Untuk menilai atau mengukur berapa baik dari setiap rupiah modal sendiri yang dijadikan jaminan utang jangka panjang,

g) Untuk menilai berapa dana pinjaman yang segera akan ditagih, terdapat sekian kali modal sendiri dimiliki.

\section{a. Dept To Asset Ratio (Rasio utang atas modal) \\ Dept to asset ratio atau dept ratio} merupakan rasio yang digunakan untuk mengukur perbandingan antara total utang dengan total aktiva. Dengan kata lain seberapa besar utang perusahaan 
berpengaruh terhadap pengelolaan aktiva. Dari haril pengukuran ini apabila rasio tinggi, artinya pendanaan dengan utang semakin banyak, maka semakin sulit bagi perusahaan untuk memperoleh tambahan pinjaman karena dikhawatirkan perusahaan tidak mampu menutupi utang-utangnya dengan aktiva yang dimilikinya. Demikian pula bila rasionya rendah, semakin kecil perusahaan dibiayai dengan utang.

\section{b. Dept to Equity Ratio (Rasio} Utang atas Ekuitas)

Kasmir (2015:167) Rasio ini merupakan rasio yang digunakan untuk menilai utang dengan ekuitas. Rasio ini dicari dengan cara membandingkan antara seluruh utang, termasuk utang lancar dan seluruh ekuitas. Rasio ini digunakan untuk mengetahui jumlah dana yang disediakan peminjam (kreditor) dengan pemilik perusahaan. Dengan kata lain, rasio ini berfungsi untuk mengetahui setiap rupiah modal sendiri yang dijadikan untuk jaminan utang. Bagi bank (kreditor), semkin besar rasio ini akan semakin tidak menguntungkan karena akan semakin besar resiko yang ditanggung atas kegagalan yang mungkin terjadi diperusahaan. Namun bagi perusahaan justru semakin besar rasio akan semakin baik. Sebaliknya jika rasio ini rendah semakin tinggi tingkat pendanaan yang disediakan pemilik atau semakin besar batas pengamanan bagi peminjam jika terjadi kerugian atau penyusutan terhadap total aktiva. Rasio ini memberikan petunjuk umum tentang kelayakan dan risiko keuangan perusahaan.

\section{Rasio Aktivitas}

Kasmir (2015 : 172) menyatakan rasio aktivitas merupakan rasio yang digunakan untuk mengukur tingkat efisiensi pemanfaatan sumber daya perusahaan ( penjualan, sediaan, penagihan utang, dan lainnya) atau untuk menilai kemampuan perusahaan dalam melaksanakan aktivitas sehari hari. Rasio aktivitas terdiri dari perputaran piutang, hari rata-rata penagihan piutang, perputaran sediaan, hari rata-rata penagihan sediaan, perputaran modal kerja, perputaran aktiva tetap, dan perputaran aktiva. Tujuan dan manfaat rasio aktivitas antara lain :

a) Untuk mengukur berapa lama penagihan piutang selama satu periode atau beberapa kali dana yang ditanam dalam piutang ini berputar dalam satu periode.

b) Untuk menghitung hari rata-rata penagihan piutang (days of receivable), dimana hasil perhitungan ini menunjukkan 
jumlah hari piutang tersebut ratarata tidak dapat tertagih.

c) Untuk menghitung beberapa hari rata-rata sediaan tersedia dalam gudang.

d) Untuk mengukur berapa kali dana yang ditanamkan dalam modal kerja berputar dalam satu periode atau beberapa penjualan yang dapat dicapai oleh setiap modal kerja yang digunakan (working capital turn over).

e) Untuk mengukur berapa kali dana yang ditanamkan dalam aktiva tetap berputar dalam satu periode.

f) Untuk mengukur penggunakaan semua aktiva perusahaan dibandingkan dengan penjualan.

a. Perputaran Aktiva Tetap (Fixed Asset Turn Over)

Kasmir (2015:184) rasio ini merupakan rasio yang digunakan untuk mengukur berapa kali dana yang ditanam dalam aktiva tetap berputar dalam satu periode. Atau dengan kata lain untuk mengukur apakah perusahaan sudah menggunakan kapasitas aktiva tetap sepenuhnya atau belum.

\section{b. Perputaran Aktiva (Asset Turn Over)}

Kasmir (2015:185) perputaran aktiva merupakan rasio yang digunakan untuk mengukur perputaran semua aktiva yang dimilki perusahaan dan mengukur berapa jumlah penjualan yang diperoleh dari tiap rupiah aktiva.

\section{Rasio Profitabilitas}

Menurut Kasmir (2015:196), Rasio Profitabilitas merupakan rasio untuk menilai kemampuan perusahaan dalam mencari keuntungan. Rasio ini juga memberikan ukuran tingkat efektifitas manajemen suatu perusahaan. Hal ini menunjukkan oleh laba yang dihasilkan dari penjualan dan pendapatan investasi. Tujuan dan manfaat rasio profitabilitas bagi perusahaan maupun bagi pihak luar perusahaan yaitu :

a) Untuk mengukur atau menghitung laba yang diperoleh perusahaan dalam suatu periode tertentu.

b) Untuk menilai posisi laba perusahaan tahun sebelumnya dengan tahun sekarang

c) Untuk menilai perkembangan laba dari waktu ke waktu

d) Untuk menilai besarnya laba bersih sesudah pajak dengan modal sendiri

e) Untuk mengukur produktifitas seluruh dana perusahaan yang digunakan baik modal pinjaman maupun modal sendiri

f) Untuk mengukur produktifitas dari seluruh dana perusahaan yang digunakan baik modal sendiri 
a. Profit Margin (Profit Margin on sales)

Kasmir (2015:199) margin laba atas penjualan merupakan salah satu rasio yang digunakan untuk mengukur margin laba atas penjualan. Cara mengukurnya adalah dengan membandingkan laba bersih setelah pajak dengan penjualan bersih.

\section{b. Gross Profit Margin}

Bambang (2015:118) rasio ini adalah perhitungan laba kotor dengan penjualan sehingga menghasilkan laba untuk setiap rupiah penjualan. Rasio ini juga mengukur untuk keuntungan yang diperoleh oleh modal-modal yang digunakan untuk menyebarkan operasional baik modal yang berasal dari pemilik atau modal asing.

\section{c. Net Profit Margin}

Kasmir (2015:201) Margin laba bersih merupakan ukuran keuntungan dengan membandingkan antara laba setelah bunga dan pajak dibandingkan dengan penjualan. Rasio ini menunjukkan pendapatan bersih perusahaan atas penjualan. Dapat disimpulkan margin laba kotor tidak mengalami perubahan berarti, sedangkan margin laba bersih justru turun sangat drastis. Hal ini berarti kemungkinan peningkatnya biaya tidak langsung yang relatif tinggi terhadap penjualan atau mungkin juga karena beban pajak yang juga tinggi untuk periode tersebut.

d. ROI (Invesment On Invesment)

Kasmir (2015:203) Hasil pengembalian investasi atau lebih dikenal dengan nama return on invesment merupakan rasio yang menunjukkan hasil (return) atas jumlah aktiva yang digunakan dalam perusahaan. Return on invesment juga merupakan suatu ukuran tentang efektivitas manajemen dalam mengelola investasinya. Disamping itu, hasil pengembalian investasi menunjukkan produktivitas dari seluruh dana perusahaan, baik modal pinjaman maupun modal sendiri. Semakin kecil (rendah) rasio ini, semakin kurang baik, demikian pula sebaliknya artinya, rasio ini digunakan untuk mengukur efektifitas dari keseluruhan operasi perusahaan.

\section{e. ROA (Invesment On Asset)}

Menurut harahap (2009:305) Rasio ini merupakan perbandingan antara laba bersih dengan total aset. Rasio ini menunjukka berapa besar laba bersih diperoleh perusahaan bila diukur dari nilai asetnya. Semakin besar rasionya semakin bagus karena perusahaan dianggap mampu dalam menggunakan aset yang dimilikinya secara efektif untuk menghasilkan laba. 


\section{Du Pont System}

\section{a. Pengertian Du Pont System}

Du Pont memiliki cara sendiri dalam menganalisis laporan keuangan, hampir sama dengan analisis laporan keuangan biasa namun pendekatannya lebih integratif dan menggunakan komposisi laporan sebagai analisisnya dan mengurai hubungan pos-pos laporan keuangan sampai detail (harahap, 2015:333)

\section{b. Perhitungan Du Pont System}

Menurut Hanafi (2013:53) menggunakan Du Pont System akan dapat dilihat Return On Invesment yang dihasilkan melalui perkalian antara keuntungan dari komponen penjualan serta efesiensi penggunaan total aktiva didalam menghasilkan keuntungan. Analisis $d u$ pont system dapat juga dikembang dengan memasukkan unsur penggunaan Financial leverage, yaitu dengan mengubah ROI menjadi ROE. Ada beberapa hal yang dapat dilakukan menajer keuangan untuk menaikkan ROE, antara lain

1. Menaikkan ROI dengan menaikkan NPM atau TATO, atau keduanya dapat mempertahankan tingkat hutang.

2. Menaikkan utang (financial leverage) dengan mempertahankan ROI.
3. Menaikkan ROI dan utang bersamaan.

c. Rasio dalam Metode Du Pont System

Rasio-rasio yang digunakna dalam $d u$ pont system menurut Arief dan Edi (2016:75) adalah sebagai berikut :

1) Asset Turn Over menunjukkan kemampuan perusahaan dalam mengelola seluruh aset atau investasi untuk menghasilkan pejualan.

2) Net Profit Margin menunjukkan berapa besar keuntungan bersih yang diperoleh perusahaan.

3) Return On Invesment rasio ini mengukur tingkat pengembalian dari bisnis atas seluruh asset yang ada.

4) Asset Leverage sering juga disebut dengan pengganda ekuitas (equity multiplier), menggambarkan seberapa besar ekuitas atau modal dibandingkan dengan total aktiva perushaan atau seberapa besar aktiva dibiayai utang.

5) Return On Equity rasio ini mengukur pengembalian dari bisnis atas seluruh modal yang ada. ROE dalam $d u$ pont system dihitunga dengan mengalikan ROA dengan equity multiplier.

d. Keunggulan Metode Du Pont System 
Menurut Munawir (2010:91-92) adapun keunggulan analisis $d u$ pont antara lain :

a) Sebagai alat satu teknik analisis keuangan yang bersifat menyeluruh dan manajemen bisa mengetahui tingkat efisiensi pendayagunaan aset.

b) Dapat membandingkan efisiensi penggunaan ekuitas pada perusahaannya dengan perusahaan lain yang sejenis, sehingga dapat diketahui apakah perusahaannya berada di bawah, sederajat atau di atas rata-rata.

c) Dapat digunakan untuk mengukur efisiensi tindakan-tindakan yang dilakukan oleh divisi atau bagian, yaitu dengan mengalokasikan semua beban dan ekuitas ke dalam bagian yang bersangkutan.

d) Dapat digunakan untuk mengukur profitabilitas dari masing-masing produkyang dihasilkan oleh perusahaan.

e) Dapat digunakan untuk keperluan kontrol, juga berguna untuk keperluan perencanaan.

\section{Kinerja Keuangan}

a. Pengertian Kinerja Keuangan
Menurut munawir $(2010: 30)$,
kinerja keuangan perusahaan
merupakan satu diantara dasar

penelitian mengenai kondisi keuangan perusahaan yang dilakukan berdasarkan analisa terhadap rasio keuangan perusahaan. Pihak yang kepentingan sangat memerlukan hasil dari pengukuran kinerja keuangan perusahaan untuk dapat melihat kondisi perusahaan dan tingkat keberhasilan perusahaan dalam menjalankan kegiatan operasional.

\section{b. Menilai Kinerja Keuangan}

Menurut Fahmi (2011:03) caa menganalisis kinerja keuangan suatu perusahaan secara umum, yaitu :

1) Melakukan review terhadap data laporan keuangan, bertujuan agar laporan keuangan yang sudah dibuat tersebut sesuai dengan penerapan kaidah-kaidah yang berlaku umum dalam dunia akutansi sehingga hasil laporan keuangan tersebut dapat dipertanggung jawabkan.

2) Melakukan perhitungan, penerapannya disesuaikan dengan kondisi dan permasalahan yang sedang dilakukan sehingga hasil dari perhitungan tersebut akan memberikan suatu kesimpulan sesuai dengan analisis yang diinginkan.

3) Melakukan perbandingan terhadap hasil hitungan yang telah diperoleh, hasil perhitungan yang telah 
diperoleh tersebut kemudian dilakukan perbandingan dengan hasil perhitungan dari beberapa perusahaan lainnya.

4) Melakukan penafsiran (interpretation) terhadap berbagai permasalahan yang ditemukan, yang bertujuan untuk melihat apaapa saja permasalahan dan kendala-kendala yang dialami oleh perusahaan tersebut. Mencari dan memberikan pemecahan masalah (solution) terhadap berbagai permasalahan yang ditemukan, setelah ditemukan berbagai permasalahan yang dihadapi maka dicarikan solusi guna memberikan suatu input atau masukan agar apa yang menjadi kendala dan hambatan selama ini dapat terselesaikan.

\section{c. Tujuan Menilai Kinerja Keuangan}

Ada empat tujuan dilaksanakannya pengukuran kinerja keuangan perusahaan (Munawir (2012:31) yakni :

1) Untuk mengetahui tingkat likuiditas, yaitu kemampuan perusahaan dalam memenuhi kewajiban keuangan yang harus segera diselesaikan pada saat ditagih.

2) Untuk mengetahui tingkat solvabilitas, yaitu kemampuan perusahaan untuk memenuhi kewajiban keuangannya apabila perusahaan tersebut dilikuidasi, kewajiban keuangan yang dimaksud mencakup keuangan jangka pendek maupun jangka panjang.

3) Untuk mengetahui tingkat profitabilitas atau rentabilitas, yaitu kemampuan perusahaan dalam menghasilkan laba selama periode tertentu dengan menggunakan aktiva atau modal secara produktif.

4) Untuk mengetahui tingkat stabilitas, yaitu kemampuan perusahaan dalam enjalankan dan mempertahankan usahanya sehingga tetap stabil. Kemampuan yang dimaksud diukur dari kemampuan perusahaan membayar pokok hutang dan beban bunga tepat pada waktunya.

\subsection{Kerangka Pemikiran}

Peranan kerangka pemikiran dalam penelitian sangat penting untuk menggambarkan secara tepat obyek yang akan diteliti dan untuk memberikan suatu gambaran yang jelas dan sistematis. Penelitian ini dimaksud untuk mengevaluasi perbandingan kinerja keuangan perusahaan berdasarkan metode financial ratio dan du pont system PT Angkasa Pura I dan 
PT Angkasa Pura II periode 2013-2016

Penjelasan tentang kerangka pemikiran

diatas dapat di ilustrasi sebagai berikut : 
Gambar 2.1.

Kerangka Pemikiran Penelitian

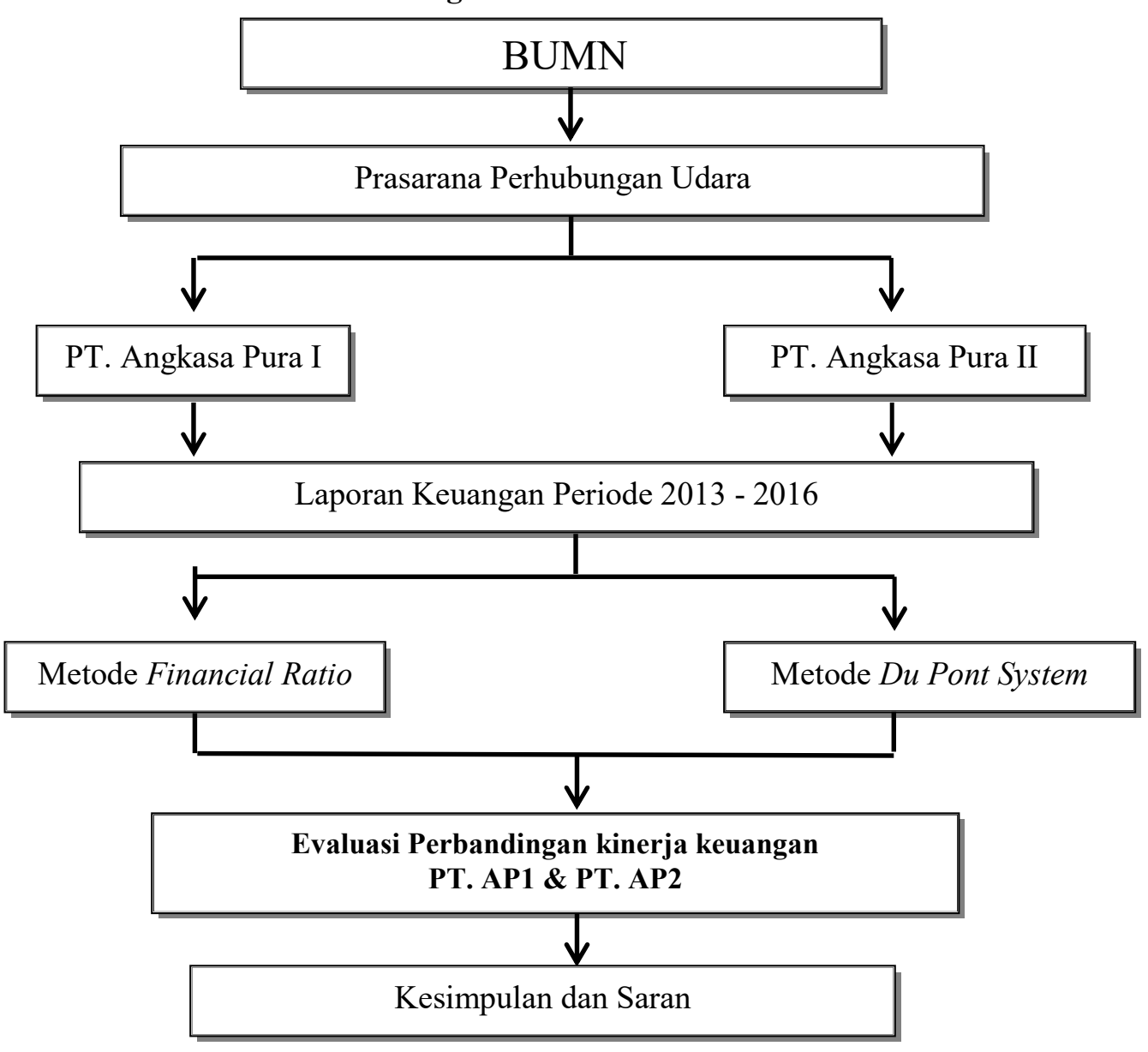

Sumber data : Diolah penulis

Keterangan :

Dalam menentukan evaluasi kinerja keuangan perusahaan berdasarkan metode financial ratio dan du pont system pada PT. AP I dan PT. AP II periode 2013-2016. Maka, pertama yang dilihat adalah laporan keuangan kedua perusahaan. Yang kedua, menganalisis laporan keuangan perusahaan berdasarkan metode financial ratio dan du pont system dan terakhir mengevaluasi kinerja keuangan keuangan perusahaan, dimana dapat menentukan manakah dari kedua perusahaan tersebut yang kinerja keuangannya lebih baik.

\subsection{Hipotesis Penelitian}


Penelitian ini menggunakan uji Mann-Whitney U-tes. U-test digunakan untuk menguji signifikansi hipotesis komparatif dua sampel independen bila datanya ordinal. Test ini merupakan test yang terbaik untuk menguji hipotesis komparatif dua sampel independen bila datanya ordinal, bila datanya interval maka perlu dirubah dulu kedata ordinal. Bila data masih berbentuk interval, sebenarnya dapat menggunakan t-test untuk pengujiannya, tetapi bila asumsi t-test tidak dipenuhi (misalnya data harus normal), maka test ini tidak dapat digunakan. (Sigiyono. 2009:324).

\section{Kriteria Pengujian Hipotesis :}

"HO diterima bila ada Perbedaan kinerja keuangan antara PT. Angkasa Pura I dan PT. Angkasa Pura II"

\section{METODE PENELITIAN}

\section{Jenis dan Sumber Data \\ Jenis Data}

Jenis data yang digunakan dalam penelitian ini adalah data kuantatif menurut Sugiyono (2012 : 23) "data kuantitatif adalah data yang berbentuk angka" sesuai dengan bentuknya, data kuantitatif dapat diolah atau dianalisis menggunakan teknik perhitungan matematika atau tatistika. Data tersebut seperti nilai akun-akun yang terdapat di laporan keuangan perusahaan (neraca, laporan laba rugi) selama periode 2013-2016, profil perusahaan, arsip dan dokumen lain yang didapat dari perusahaan dan studi pustaka.

\section{Sumber Data}

Data yang digunakan dalam penelitian ini adalah sekunder, menurut Sugiyono (2012 : 127) "data sekunder merupakan data yang bersumber tidak langsung memberikan data pada pengumpul data, misalnya lewat orang lain atau lewat dokumen". Data sekunder antara lain disajikan dalam bentuk data-data, dokumen, tabel-tabel mengenai topik penelitian.

\section{Teknik Pengumpulan Data}

Menurut Suharsimi (2010:265) "teknik pengumpulan data adalah alat bantu yang dipilih dan digunakan oleh penelitian dalam kegiatannya mengumpulkan data agar kegiatan tersebut menjai sistematis dan dipermudah olehnya, maka penelitian ini menggunakan teknik pengumpulan data dokumentasi atau studi dokumen yaitu mengumpulkan data yang telah tersedia dalam bentuk laporan tahunan perushaaan selama periode 2013-2016. 


\section{Metode Penelitian}

Metode penelitian adalah suatu cara atau teknis yang digunakan dalam sebuah penelitian. Metode yang digunakan dalam penelitian ini adalah deskriptif kuantitatif. Variabel tersebut dibahas dan diuraikan secara kuantitatif yang disusun secara sistematis untuk menilai evaluasi perbandingan kinerja keuangan perusahaan berdasarkan metode financial ratio dan $d u$ pont system pada PT. Angkasa Pura I dan PT. Angkasa Pura II periode 2013-2016. Tata cara penilaian dilihat dari besar kecilnya hasil perhitungan rasio keuangan masing-masing perusahaan.

\section{Teknik Analisis Data}

Dalam penelitian ini menggunakan teknik analisi data Deskriptif Compere dimana variabel mandiri ialah kinerja keuangan perusahaan dengan melihat hasil dari perhitungan metode financial ratio dan $d u$ pont system setelah itu di komparatifkan antara PT. Angkasa Pura I dan PT Angkasa Pura II yang dapat disumpulkan manakah dari kedua perusahaan tersebut yang tergolong dalam kinerja keungan baik maupun tidak baik dengan menggunakan uji beda independent t-test dari aplikasi spss versi 22 untuk menjawab hipotesis.

\section{ANALISIS HASIL PENELITIAN \\ DAN PEMBAHASAN}

\section{Hasil Analisis Data dan Pembahasan \\ Financial Ratio}

\begin{abstract}
a. Rasio Likuiditas
Rasio Likuiditas menggambarkan kemampuan perusahaan untuk menyelesaikan kewajiban jangka pendeknya. Rasio-rasio ini dapat dihitung melalui sumber informasi tentang modal kerja yaitu pos-pos aktiva lancar dan hutang lancar.
\end{abstract}


Tabel

Data ringkasan laporan Keuangan PT. AP I dan PT. AP II

\begin{tabular}{|c|c|c|c|c|c|}
\hline \multicolumn{2}{|c|}{ keterangan } & Aktiva Lancar & Persediaan & $\begin{array}{c}\text { Kas dan Setara } \\
\text { kas }\end{array}$ & Utang Lancar \\
\hline \multirow{4}{*}{$\begin{array}{l}\overrightarrow{8} \\
\stackrel{4}{0}\end{array}$} & 2013 & 1.910 .507 .133 & 7.836 .410 & 475.064 .108 & 2.486 .332 .599 \\
\hline & 2014 & 2.562 .430 .588 & 5.137 .578 & 1.209 .659 .874 & 2.778 .608 .738 \\
\hline & 2015 & 2.918 .088 .601 & 6.810 .677 & 1.537 .900 .677 & 2.522 .010 .619 \\
\hline & 2016 & 5.952 .478 .251 & 6.399 .594 & 4.678.757.791 & 3.678 .807 .284 \\
\hline \multirow{4}{*}{ 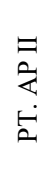 } & 2013 & 2.511 .114 .818 .092 & 13.375 .651 .581 & 1.502 .843 .630 .698 & 884.097 .452 .370 \\
\hline & 2014 & 2.020 .281 .811 .676 & 14.119 .032 .726 & 1.009.767.356.535 & 1.337 .182 .635 .587 \\
\hline & 2015 & 3.986.324.542.389 & 11.010 .737 .182 & 2.910 .883 .208 .626 & 2.224.995.194.042 \\
\hline & 2016 & 7.741 .298 .321 .815 & 9.774 .203 .145 & 6.586 .142 .271 .009 & 3.155 .492 .272 .688 \\
\hline
\end{tabular}

Tabel

Hasil Analisis Rasio Likuiditas PT. AP I dan PT. AP II

\begin{tabular}{|c|r|r|r|r|r|r|}
\hline \multirow{2}{*}{ Keterangan } & \multicolumn{3}{|c|}{ PT. Angkasa Pura I } & \multicolumn{3}{c|}{ PT. Angkasa Pura II } \\
\cline { 2 - 7 } & $\begin{array}{l}\text { Current } \\
\text { Ratio }\end{array}$ & $\begin{array}{l}\text { Quick } \\
\text { Ratio }\end{array}$ & $\begin{array}{l}\text { Cash } \\
\text { Ratio }\end{array}$ & $\begin{array}{l}\text { Current } \\
\text { Ratio }\end{array}$ & $\begin{array}{l}\text { Quick } \\
\text { Ratio }\end{array}$ & $\begin{array}{l}\text { Cash } \\
\text { Ratio }\end{array}$ \\
\hline 2013 & $77 \%$ & $77 \%$ & $19 \%$ & $284 \%$ & $283 \%$ & $170 \%$ \\
\hline 2014 & $92 \%$ & $92 \%$ & $44 \%$ & $151 \%$ & $150 \%$ & $76 \%$ \\
\hline 2015 & $116 \%$ & $115 \%$ & $61 \%$ & $179 \%$ & $179 \%$ & $131 \%$ \\
\hline 2016 & $162 \%$ & $162 \%$ & $127 \%$ & $245 \%$ & $245 \%$ & $209 \%$ \\
\hline Rata-rata & $112 \%$ & $111 \%$ & $63 \%$ & $215 \%$ & $214 \%$ & $146 \%$ \\
\hline
\end{tabular}

Tabel

Gross Section Rasio Likuiditas PT. AP I dan PT. AP II

\begin{tabular}{|c|r|r|r|r|r|r|}
\hline \multirow{2}{*}{ Keterangan } & \multicolumn{3}{|c|}{ PT. Angkasa Pura I } & \multicolumn{3}{c|}{ PT. Angkasa Pura II } \\
\cline { 2 - 7 } & $\begin{array}{l}\text { Current } \\
\text { Ratio }\end{array}$ & $\begin{array}{l}\text { Quick } \\
\text { Ratio }\end{array}$ & $\begin{array}{l}\text { Cash } \\
\text { Ratio }\end{array}$ & $\begin{array}{l}\text { Current } \\
\text { Ratio }\end{array}$ & $\begin{array}{l}\text { Quick } \\
\text { Ratio }\end{array}$ & $\begin{array}{l}\text { Cash } \\
\text { Ratio }\end{array}$ \\
\hline \multirow{2}{*}{2014} & $15 \%$ & $16 \%$ & $24 \%$ & $-133 \%$ & $132 \%$ & $-94 \%$ \\
\hline 2015 & $23 \%$ & $23 \%$ & $17 \%$ & $28 \%$ & $29 \%$ & $55 \%$ \\
\hline 2016 & $46 \%$ & $46 \%$ & $66 \%$ & $66 \%$ & $66 \%$ & $78 \%$ \\
\hline
\end{tabular}




\section{Gambar}

Hasil Analisis Rasio Likuiditas PT. AP I

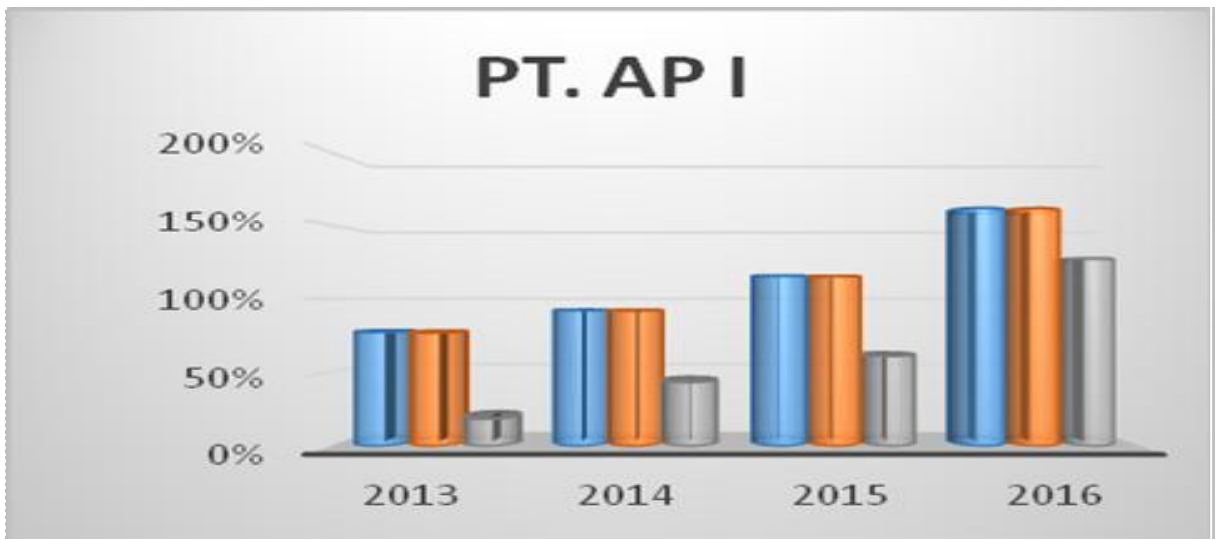

Gambar

Hasil Analisis Rasio Likuiditas PT. AP II

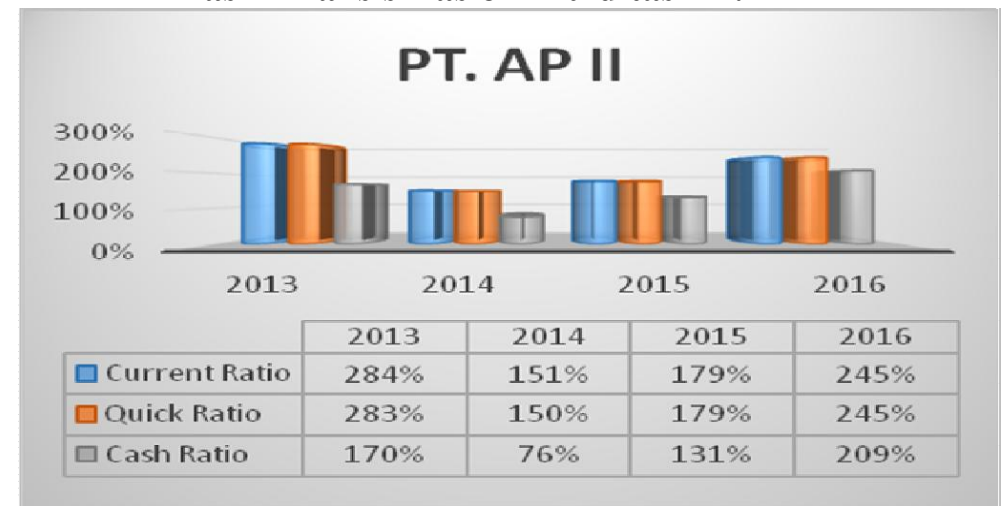

Berdasarkan tabel di atas dapat diketahui bahwa rasio likuiditas perusahaan mengalami fluktuasi. Ratarata nilai tertinggi ada pada PT. AP II sedangkan pada PT. AP I berada di bawah atau lebih rendah dari nilai ratarata pada PT. AP II. Penjelasan per perusahaan adalah sebagai berikut :

a. Berdasarkan gambar kurva likuiditas pada PT. Angkasa Pura I tahun 2013-2016 mengalami kondisi fluktuasi dengan pembuktian adanya perubahan current ratio, quick ratio, dan cash ratio serta menunjukkan kenaikan yang artinya perusahaan dalam kondisi kinerja yang baik.

b. Berdasarkan gambar kurva likuiditas pada PT. Angkasa Pura II tahun 2013-2016 mengalami kondisi fluktuasi dengan pembuktian adanya perubahan current ratio, quick ratio, dan cash ratio serta menunjukkan 
kecenderungan menurun yang artinya perusahaan dalam kondisi kinerja yang kurang baik. Hal tersebut diketahui pada perhitungan cash ratio yang menunjukkan tingkat rasio yang berfluktuasi, artinya adanya ketidakstabilan perusahaan dalam kinerja keuangan. Namun pada PT. AP II kinerja keuangan dilihat dari rata- rata rasio likuiditas lebih unggul dari PT. AP I.

\section{b. Rasio Solvabilitas}

Rasio Solvabilitas menggunakan kemampuan perusahaan dalam membayar kewajiban jangka panjangnya atau kewajiban-kewajiban apabila perusahaan dilikuidasi.

Tabel

Data ringkasan laporan Keuangan PT. AP I dan PT. AP II

\begin{tabular}{|c|c|c|c|c|}
\hline \multicolumn{2}{|c|}{ keterangan } & Total Aktiva & Total Utang & Total Equity \\
\hline \multirow{4}{*}{$\begin{array}{l}\overrightarrow{2} \\
\dot{a}\end{array}$} & 2013 & 13.238 .494 .078 & 3.708 .678 .435 & 9.529 .815 .643 \\
\hline & 2014 & 15.730 .135 .523 & 5.234 .257 .221 & 10.495 .878 .303 \\
\hline & 2015 & 16.458 .661 .928 & 5.487 .900 .960 & 10.970 .760 .968 \\
\hline & 2016 & 23.310 .852 .886 & 11.432 .817 .859 & 11.878 .035 .027 \\
\hline \multirow{4}{*}{$\begin{array}{l}= \\
\stackrel{4}{2} \\
\dot{2} \\
\dot{2}\end{array}$} & 2013 & 13.398 .620 .591 .318 & 1.242 .668 .280 .415 & 12.155 .952 .310 .903 \\
\hline & 2014 & 15.278 .183 .057 .126 & 2.060 .300 .467 .117 & 13.217 .882 .590 .009 \\
\hline & 2015 & 20.207 .597 .779 .792 & 3.962 .589 .847 .307 & 16.245 .007 .932 .485 \\
\hline & 2016 & 27.964 .799 .599 .909 & 8.049 .688 .579 .384 & 19.915 .111 .020 .525 \\
\hline
\end{tabular}

Tabel

Hasil Analisis Rasio Solvabilitas PT. AP I dan PT. AP II

\begin{tabular}{|c|r|r|r|r|}
\hline \multirow{2}{*}{ Keterangan } & \multicolumn{2}{|c|}{ PT. Angkasa Pura I } & \multicolumn{2}{c|}{ PT. Angkasa Pura II } \\
\cline { 2 - 5 } & $\begin{array}{c}\text { Debt to } \\
\text { Asset Ratio }\end{array}$ & $\begin{array}{c}\text { Debt to } \\
\text { Equity Ratio }\end{array}$ & $\begin{array}{c}\text { Debt to } \\
\text { Asset Ratio }\end{array}$ & $\begin{array}{c}\text { Debt to Equity } \\
\text { Ratio }\end{array}$ \\
\hline 2013 & $28 \%$ & $39 \%$ & $9 \%$ & $10 \%$ \\
\hline 2014 & $33 \%$ & $50 \%$ & $13 \%$ & $16 \%$ \\
\hline 2015 & $33 \%$ & $50 \%$ & $20 \%$ & $24 \%$ \\
\hline 2016 & $49 \%$ & $96 \%$ & $29 \%$ & $40 \%$ \\
\hline Rata-rata & $36 \%$ & $59 \%$ & $18 \%$ & $23 \%$ \\
\hline
\end{tabular}


Tabel

Gross Section Rasio Solvabilitas PT. AP I dan PT. AP II

\begin{tabular}{|c|r|r|r|r|}
\hline \multirow{2}{*}{ Keterangan } & \multicolumn{2}{|c|}{\begin{tabular}{c} 
PT. Angkasa Pura I \\
Debt to \\
\cline { 2 - 5 }
\end{tabular}} & $\begin{array}{c}\text { Debt to } \\
\text { Asset Ratio }\end{array}$ & \multicolumn{2}{c|}{$\begin{array}{c}\text { PT. Angkasa Pura II } \\
\text { Equity Ratio } \\
\text { Asset Ratio }\end{array}$} & $\begin{array}{c}\text { Debt to } \\
\text { Equity Ratio }\end{array}$ \\
\hline 2014 & $5 \%$ & $11 \%$ & $4 \%$ & $6 \%$ \\
\hline 2015 & $0 \%$ & $0 \%$ & $6 \%$ & $8 \%$ \\
\hline 2016 & $16 \%$ & $46 \%$ & $9 \%$ & $16 \%$ \\
\hline
\end{tabular}

Gambar

Hasil Analisis Rasio Solvabilitas PT. AP I

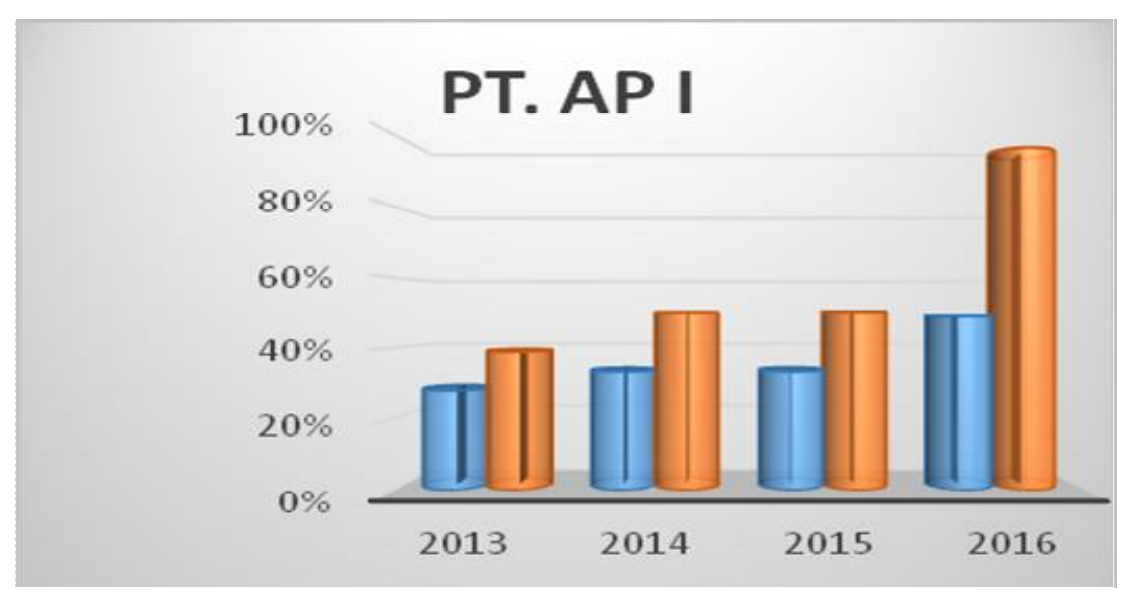

Gambar

Hasil Analisis Rasio Solvabilitas PT. AP II

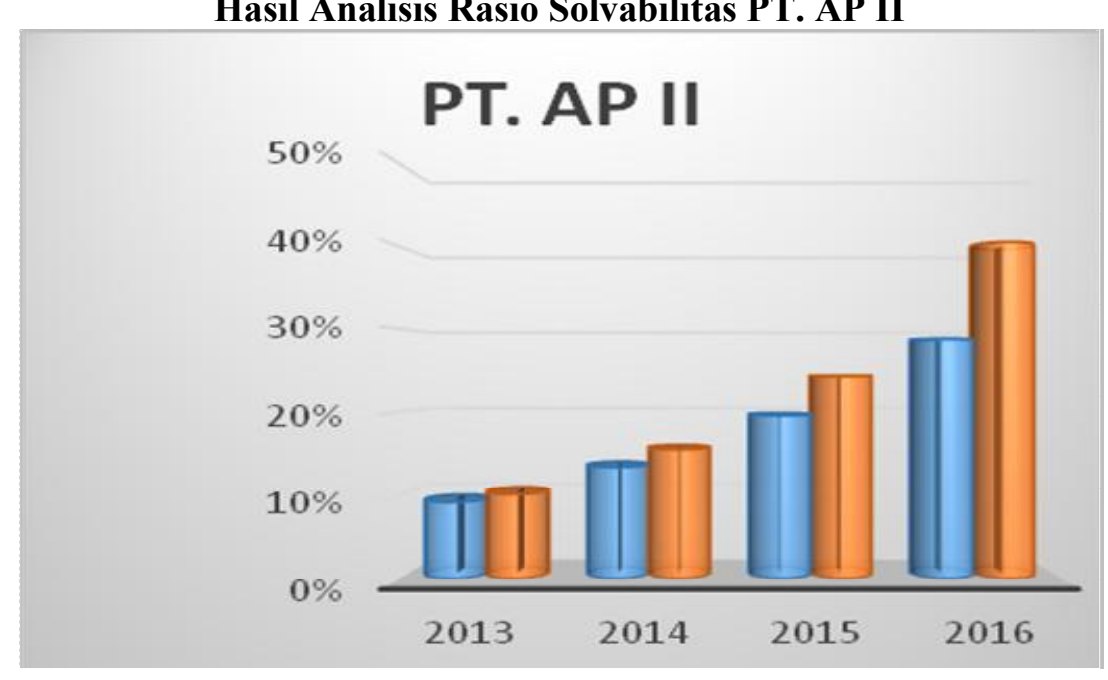


Berdasarkan tabel di atas dapat diketahui bahwa rasio solvabilitas perusahaan mengalami fluktuasi. Ratarata nilai tertinggi ada pada PT. AP I sedangkan pada PT. AP II berada di bawah atau lebih rendah dari nilai ratarata pada PT. AP I. Penjelasan per perusahaan adalah sebagai berikut :

1. Berdasarkan gambar di atas kurva solvabilitas pada PT. Angkasa Pura I tahun 2013-2016 mengalami kondisi fluktuasi dengan pembuktian adanya perubahan $d e b t$ to asset ratio dan debt to equity ratio serta menunjukkan kenaikan yang artinya perusahaan dalam kondisi kinerja yang baik. Hal tersebut diketahui pada perhitungan debt to equity ratio yang menunjukkan tingkat rasio yang baik dimana kestabilan perusahaan dalam kinerja keuangan. Meningkatnya kedua rasio ini menunjukkan bahwa kewajibankewajiban yang dimiliki perusahaan semakin bertambah. Tahun 2016 nilai rasio yang diperoleh cukup tinggi terutama pada debt to asset ratio yang artinya rsiko hutang terhadap aktiva yang dimiliki perusahaan juga semakin tinggi. Pada debt to equity ratio juga mengalami peningkatan setiap tahunnya, hal tersebut menunjukkan bahwa perusahaan lebih menggunakan pembiayaan dari modal sendiri dibandingkan dengan penggunaan biaya dari luar. Pada PT. AP I kinerja keuangan dilihat dari rasio solvabilitas lebih unggul dari PT. AP II.

2. Berdasarkan gambar kurva solvabilitas pada PT. Angkasa Pura II tahun 2013-2016 mengalami kondisi fluktuasi dengan pembuktian adanya perubahan debt to asset ratio dan debt to equity ratio serta menunjukkan kenaikan yang artinya perusahaan dalam kondisi kinerja yang baik. Meningkatnya kedua rasio ini menunjukkan bahwa kewajibankewajiban yang dimiliki perusahaan semakin bertambah. Tahun 2016 nilai rasio yang diperoleh cukup tinggi terutama pada debt to asset ratio yang artinya rsiko hutang terhadap aktiva yang dimiliki perusahaan juga semakin tinggi. Pada debt to equity ratio juga mengalami peningkatan setiap tahunnya, hal tersebut menunjukkan bahwa perusahaan lebih menggunakan pembiayaan dari modal sendiri dibandingkan dengan penggunaan biaya dari luar. Namun pada PT. 
AP II kinerja keuangan dilihat dari rasio solvabilitas lebih rendah dari PT. AP I.

\section{c. Rasio Aktivitas}

Rasio aktivitas merupakan rasio yang digunakan untuk mengukur tingkat efisiensi pemanfaatan sumber daya perusahaan (penjualan, sediaan, penagihan utang, dan lainnya) atau untuk menilai kemampuan perusahaan dalam melaksanakan aktivitas sehari hari.

Tabel

Data ringkasan laporan Keuangan PT. AP I dan PT. AP II

\begin{tabular}{|c|c|c|c|c|}
\hline \multicolumn{2}{|c|}{ keterangan } & Penjualan & Aktiva tetap & Total Aktiva \\
\hline \multirow{4}{*}{$\begin{array}{l}\vec{z} \\
\dot{a} \\
\dot{a}\end{array}$} & 2013 & 2.963.212.512 & 11.327 .986 .945 & 13.238.494.078 \\
\hline & 2014 & 4.389 .793 .624 & 13.167 .704 .935 & 15.730 .135 .523 \\
\hline & 2015 & 4.963 .962 .842 & 13.540 .573 .327 & 16.458.661.928 \\
\hline & 2016 & 5.675 .978 .891 & 17.358 .374 .635 & 23.310 .852 .886 \\
\hline \multirow{4}{*}{ 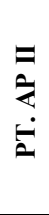 } & 2013 & 4.320 .810 .092 .185 & 10.887 .505 .773 .226 & 13.398.620.591.318 \\
\hline & 2014 & 4.889.200.035.462 & 13.257 .901 .245 .450 & 15.278.183.057.126 \\
\hline & 2015 & 5.607.023.192.943 & 16.221.273.237.403 & 20.207.597.779.792 \\
\hline & 2016 & 6.706 .069 .876 .706 & 20.223 .501 .278 .094 & 27.964.799.599.909 \\
\hline
\end{tabular}

Tabel

Hasil Analisis Rasio Aktivitas PT. AP I dan PT. AP II

\begin{tabular}{|r|r|r|r|r|}
\hline \multirow{2}{*}{ Keterangan } & \multicolumn{2}{|c|}{ PT. Angkasa Pura I } & \multicolumn{2}{c|}{ PT. Angkasa Pura II } \\
\cline { 2 - 5 } & $\begin{array}{c}\text { Perpuataran } \\
\text { Aktiva }\end{array}$ & $\begin{array}{c}\text { Perpuataran } \\
\text { Total Aktiva }\end{array}$ & $\begin{array}{c}\text { Perpuataran } \\
\text { Aktiva }\end{array}$ & $\begin{array}{c}\text { Perpuataran } \\
\text { Total Aktiva }\end{array}$ \\
\hline 2013 & 0,262 & 0,224 & 0,397 & 0,322 \\
\hline 2014 & 0,333 & 0,279 & 0,369 & 0,320 \\
\hline 2015 & 0,367 & 0,302 & 0,346 & 0,277 \\
\hline 2016 & 0,327 & 0,243 & 0,332 & 0,240 \\
\hline Rata-rata & $32 \%$ & $26 \%$ & $36 \%$ & $29 \%$ \\
\hline
\end{tabular}


Tabel

Gross Section Rasio Aktivitas PT. AP I dan PT. AP II

\begin{tabular}{|c|r|r|r|r|}
\hline \multirow{2}{*}{ Keterangan } & \multicolumn{2}{|c|}{ PT. Angkasa Pura I } & \multicolumn{2}{c|}{ PT. Angkasa Pura II } \\
\cline { 2 - 5 } & $\begin{array}{l}\text { Perpuataran } \\
\text { Aktiva }\end{array}$ & $\begin{array}{l}\text { Perpuataran } \\
\text { Total Aktiva }\end{array}$ & $\begin{array}{l}\text { Perpuataran } \\
\text { Aktiva }\end{array}$ & $\begin{array}{l}\text { Perpuataran } \\
\text { Total Aktiva }\end{array}$ \\
\hline 2014 & 0,072 & 0,055 & $-0,028$ & $-0,002$ \\
\hline 2015 & 0,033 & 0,023 & $-0,023$ & $-0,043$ \\
\hline 2016 & $-0,040$ & $-0,058$ & $-0,014$ & $-0,038$ \\
\hline
\end{tabular}

Gambar

Hasil Analisis Rasio Aktivitas PT. AP I

\section{PT. AP I}

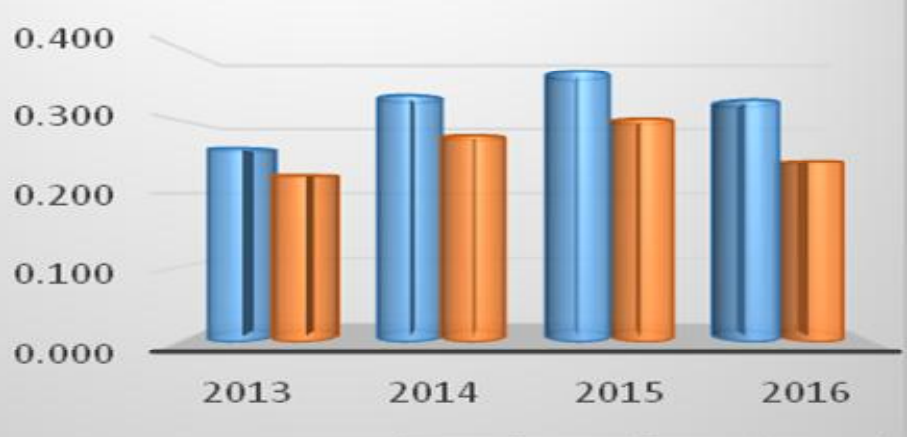

Gambar

Hasil Analisis Rasio Aktivitas PT. AP II

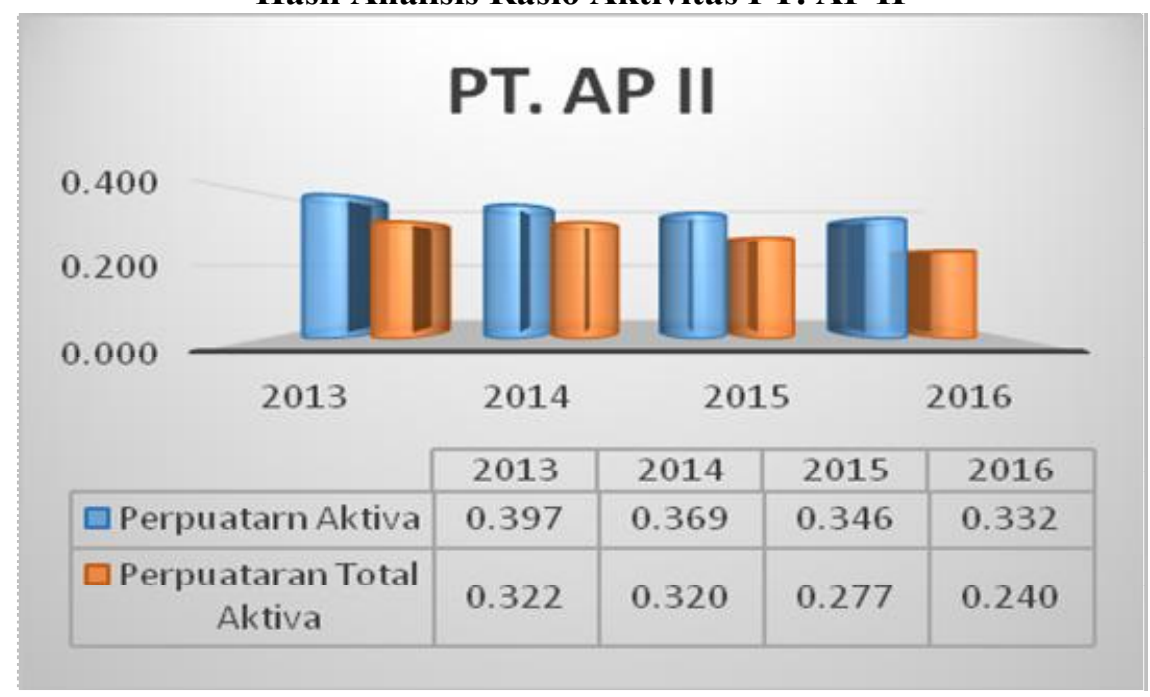


Berdasarkan tabel menunjukkan bahwa rasio aktivitas perusahaan mengalami fluktuasi. Rata-rata nilai tertinggi ada pada PT. AP II sedangkan pada PT. AP I berada di bawah atau lebih rendah dari nilai rata-rata pada PT. AP I. Penjelasan per perusahaan adalah sebagai berikut :

1. Perputaran aktiva pada tahun 2013 sebesar 0,262 kali lalu pada tahun 2014 terjadi kenaikan sebesar 0,333 kali pada tahun 2015 terjadi kenaikan sebesar 0,367 kali dan pada tahun 2016 terjadi penurunan sebesar 0,327 kali. Hal ini menunjukkan bahwa perusahaan mengalami kenaikan efesiensi penjualan dalam mengasilkan aktiva tetap perusahaan. Pada perpuataran total aktiva pada periode 2013-2016 sebesar 0,224, 0,279, 0,304, dan 0,243. Perputan total aktiva yang mengalami penurunan menunjukkan bahwa manajemen perusahaan semakin kurang baik dalam menggunakan seluruh aktiva untuk menciptakan penjualan. Karena semakin tinggi perputaran total aktiva maka semakin efisiensi perusahaan dalam menggunakan seluruh aktiva yang dimiliki untuk menghasilkan laba. Dengan demikian jika dilihat dari rata-rata perhitungan rasio aktiva pada PT. AP I lebih rendah dari PT. AP II.

2. Perpuataran aktiva pada tahun 2013 hingga 2016 pada PT. AP II menunjukkan setiap tahunnya perusahaan mengalami penurunan penjualan dalam menghasilkan aktiva tetap perusahaan. Dalam perhitungan perputaran total aktiva pada periode yang sama sebesar $0,332,0,320,0,277$, dan 0,240 dengan rata-rata perhitungan selama empat tahun sebesar $29 \%$ walaupun mengalami kenaikan dan penurunan yang fluktuasi tetapi pada PT. AP II lebih baik kinerja keuangan dari pada PT. AP I.

\section{d. Rasio Profitabilitas}

Rasio Profitabilitas merupakan rasio untuk menilai kemampuan perusahaan dalam mencari keuntungan. Rasio ini juga memberikan ukuran tingkat efektifitas manajemen suatu perusahaan. 
Tabel

Data ringkasan laporan Keuangan PT. AP I dan PT. AP II

\begin{tabular}{|c|c|c|c|c|c|c|}
\hline \multicolumn{2}{|c|}{ Keterangan } & Laba bersih & Penjualan & Laba kotor & Investasi & Total Aktiva \\
\hline \multirow{4}{*}{$\overrightarrow{\stackrel{a}{L}}$} & 2013 & 644.208 .528 & 2.963.212.512 & 811.343 .247 & 753.770 .120 & 13.238.494.078 \\
\hline & 2014 & 978.499 .416 & 4.389.793.624 & 1.158 .126 .832 & 650.613 .022 & 15.730 .135 .523 \\
\hline & 2015 & 799.029 .765 & 4.963 .962 .842 & 1.044 .983 .224 & 759.422 .126 & 16.458 .661 .928 \\
\hline & 2016 & 1.097 .947 .329 & 5.675 .978 .891 & 1.423 .461 .286 & 790.752 .819 & 23.310 .852 .886 \\
\hline \multirow{4}{*}{ 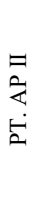 } & 2013 & 1.031 .857 .863 .592 & 4.320 .810 .092 .185 & 1.499.241.406.169 & 67.189 .799 .237 & 13.398 .620 .591 .318 \\
\hline & 2014 & 1.095 .033 .721 .716 & 4.889.200.035.462 & 1.548 .670 .123 .663 & 78.968 .873 .041 & 15.278.183.057.126 \\
\hline & 2015 & 1.676 .988 .378 .166 & 5.607 .023 .192 .943 & 2.192.096.217.033 & 78.290 .394 .065 & 20.207.597.779.792 \\
\hline & 2016 & 1.919 .217 .166 .584 & 6.706 .069 .876 .706 & 2.318 .838 .822 .129 & 77.524 .639 .174 & 27.964.799.599.909 \\
\hline
\end{tabular}

Tabel

Hasil Analisis Rasio profitabilitas PT. AP I dan PT. AP II

\begin{tabular}{|r|r|r|r|r|r|r|r|r|}
\hline \multirow{2}{*}{ Ket } & \multicolumn{4}{|c|}{ PT. Angkasa Pura I } & \multicolumn{5}{|c|}{ PT. Angkasa Pura II } \\
\cline { 2 - 10 } & GPM & NPM & \multicolumn{1}{c|}{ ROI } & \multicolumn{1}{c|}{ ROA } & GPM & NPM & \multicolumn{1}{c|}{ ROI } & \multicolumn{1}{c|}{ ROA } \\
\hline 2013 & $27 \%$ & $22 \%$ & $85 \%$ & $6 \%$ & $35 \%$ & $24 \%$ & $1536 \%$ & $11 \%$ \\
\hline 2014 & $26 \%$ & $22 \%$ & $150 \%$ & $7 \%$ & $32 \%$ & $22 \%$ & $1387 \%$ & $10 \%$ \\
\hline 2015 & $21 \%$ & $16 \%$ & $105 \%$ & $6 \%$ & $39 \%$ & $30 \%$ & $2142 \%$ & $11 \%$ \\
\hline 2016 & $25 \%$ & $19 \%$ & $139 \%$ & $6 \%$ & $35 \%$ & $29 \%$ & $2476 \%$ & $8 \%$ \\
\hline Rata-rata & $25 \%$ & $20 \%$ & $120 \%$ & $6 \%$ & $35 \%$ & $26 \%$ & $1885 \%$ & $10 \%$ \\
\hline
\end{tabular}

Tabel

Gross Section Rasio Profitabilitas PT. AP I dan PT. AP II

\begin{tabular}{|c|r|r|r|r|r|r|r|r|}
\hline \multirow{2}{*}{ Ket } & \multicolumn{3}{|c|}{ PT. Angkasa Pura I } & \multicolumn{3}{|c|}{ PT. Angkasa Pura II } \\
\cline { 2 - 9 } & GPM & NPM & ROI & ROA & GPM & NPM & ROI & ROA \\
\hline 2014 & $-1 \%$ & $1 \%$ & $65 \%$ & $1 \%$ & $-3 \%$ & $-1 \%$ & $-149 \%$ & $-1 \%$ \\
\hline 2015 & $-5 \%$ & $-6 \%$ & $-45 \%$ & $-1 \%$ & $7 \%$ & $8 \%$ & $755 \%$ & $1 \%$ \\
\hline 2016 & $4 \%$ & $3 \%$ & $34 \%$ & $0 \%$ & $-5 \%$ & $-1 \%$ & $334 \%$ & $-3 \%$ \\
\hline
\end{tabular}




\section{Gambar}

Hasil Analisis Rasio Profitabilitas PT. AP I

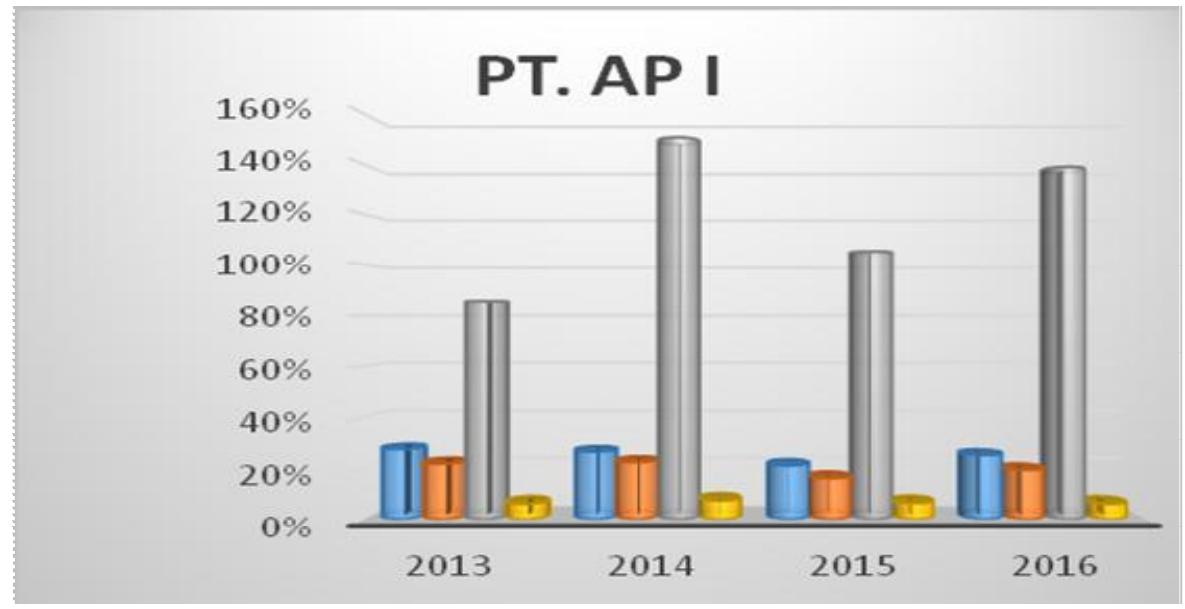

\section{Gambar}

Hasil Analisis Rasio Profitabilitas PT. AP II

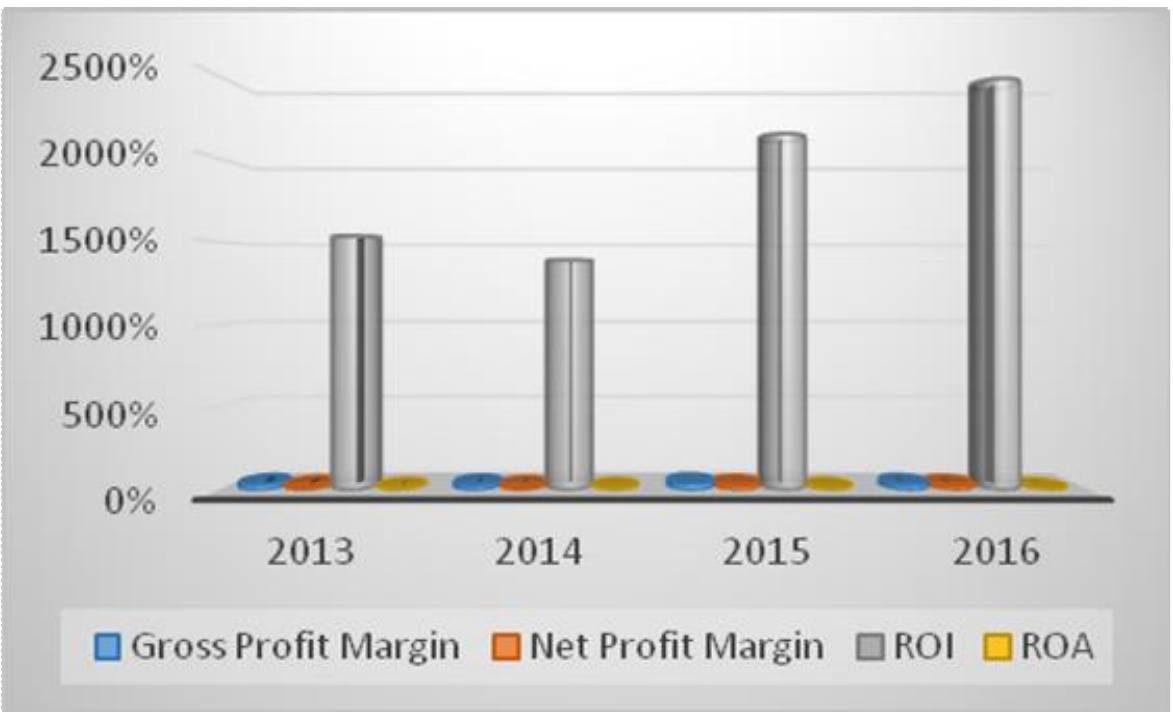

Berdasarkan

tabel

menunjukkan bahwa rasio profitabilitas perusahaan mengalami fluktuasi. Ratarata nilai tertinggi ada pada PT. AP II sedangkan pada PT. AP I berada di bawah atau lebih rendah dari nilai rata- 
rata pada PT. AP I. Penjelasan per perusahaan adalah sebagai berikut :

6. GMP pada tahun 2013 hingga 2016 mengalami peningkatan dengan rata-rata $25 \%$, hal ini menunjukkan bahwa kinerja keuangan perusahaan semakin baik atau kemampuan perusahaan dalam meningkatkan laba kotor yang diperoleh dari setiap rupiah penjualan semakin baik. NPM selama empat tahun terakhir mengalami peningkatan sebesar rata-rata $20 \%$ hal ini menunjukkan bahwa laba bersih setelah pajak yang dicapai perusahaan sebesar $88 \%$ dari volume penjualan. NPM semakin naik menunjukkan laba bersih setelah pajak yang dihasilkan dari penjualan semakin bertambah, semingga kinerja keuangan perusahaan semakin baik. ROI pada PT. AP I mengalami kenaikan sebesar 120\% hal ini menunjukkan keadaan investasi serta kemampuan perusahaan secara keseluruhan dalam mendapatkan keuntungan dengan jumlah seluruh aktiva yang tersedia dalam perusahaan dalam menghasilkan keuntungan semakin buruk. Semakin tinggi ROI, maka semakin baik pula keadaan perusahaan dalam menghasilkan keuntungan. ROE pada PT AP I sebesar $6 \%$ hal ini mengakibatkan ROE setiap tahunnya fluktuasi dimana bahwa keadaan tingkat pengembalian yang lebih kecil pada pemegang saham, karena ROE yang bernilai positif menunjukkan bahwa perusahaan dapat menghasilkan keuntungan dengan kemampuan modal sendiri yang dapat menguntungkan para pemegang saham.

7. GPM pada tahun 2013 hingga 2016 mengalami peningkatan dengan rata-rata $35 \%$, hal ini menunjukkan bahwa kinerja keuangan perusahaan semakin baik atau kemampuan perusahaan dalam meningkatkan laba kotor yang diperoleh dari setiap rupiah penjualan semakin baik. NPM selama empat tahun terakhir mengalami peningkatan sebesar rata-rata $26 \%$ hal ini menunjukkan bahwa laba bersih setelah pajak yang dicapai perusahaan sebesar $143 \%$ dari volume penjualan. NPM semakin naik menunjukkan laba bersih setelah pajak yang dihasilkan dari penjualan semakin bertambah, semingga kinerja keuangan perusahaan semakin baik. ROI pada PT. AP II mengalami kenaikan sebesar 
$1.885 \%$ hal ini menunjukkan keadaan investasi serta kemampuan perusahaan secara keseluruhan dalam mendapatkan keuntungan dengan jumlah seluruh aktiva yang tersedia dalam perusahaan dalam menghasilkan keuntungan semakin buruk. Semakin tinggi ROI, maka semakin baik pula keadaan perusahaan dalam menghasilkan keuntungan. ROE pada PT AP II sebesar $10 \%$ hal ini mengakibatkan ROE setiap tahunnya fluktuasi dimana bahwa keadaan tingkat pengembalian yang lebih kecil pada pemegang saham, karena ROE yang bernilai positif menunjukkan bahwa perusahaan dapat menghasilkan keuntungan dengan kemampuan modal sendiri yang dapat menguntungkan para pemegang saham.

\subsubsection{Du Pont System}

Du Pont memiliki cara sendiri dalam menganalisis laporan keuangan, hampir sama dengan analisis laporan keuangan biasa namun pendekatannya lebih integratif dan menggunakan komposisi laporan sebagai analisisnya dan mengurai hubungan pos-pos laporan keuangan sampai detail

Tabel

Hasil Analisis Du Pont System PT. AP I dan PT. AP II

\begin{tabular}{|c|c|c|c|r|r|r|r|r|}
\hline \multirow{2}{*}{ Ket } & \multicolumn{3}{|c|}{ PT. Angkasa Pura I } & \multicolumn{4}{c|}{ PT. Angkasa Pura II } \\
\cline { 2 - 10 } & $\begin{array}{l}\text { Perpuataran } \\
\text { Aktiva }\end{array}$ & NPM & ROI & ROE & $\begin{array}{l}\text { Perpuataran } \\
\text { Aktiva }\end{array}$ & NPM & ROI & ROE \\
\hline 2013 & 0,262 & $22 \%$ & $5 \%$ & $4 \%$ & 0,397 & $24 \%$ & $8 \%$ & $7 \%$ \\
\hline 2014 & 0,333 & $22 \%$ & $6 \%$ & $4 \%$ & 0,369 & $22 \%$ & $7 \%$ & $6 \%$ \\
\hline 2015 & 0,367 & $16 \%$ & $5 \%$ & $3 \%$ & 0,346 & $30 \%$ & $8 \%$ & $7 \%$ \\
\hline 2016 & 0,327 & $19 \%$ & $5 \%$ & $2 \%$ & 0,332 & $29 \%$ & $7 \%$ & $5 \%$ \\
\hline $\begin{array}{l}\text { Rata- } \\
\text { rata }\end{array}$ & $32 \%$ & $20 \%$ & $5 \%$ & $3 \%$ & $36 \%$ & $26 \%$ & $8 \%$ & $6 \%$ \\
\hline
\end{tabular}

Tabel 5.14

Gross Section Du pont system PT. AP I dan PT. AP II

\begin{tabular}{|c|c|c|c|c|c|c|c|c|}
\hline \multirow[b]{2}{*}{ Ket } & \multicolumn{4}{|c|}{ PT. Angkasa Pura I } & \multicolumn{4}{|c|}{ PT. Angkasa Pura II } \\
\hline & $\begin{array}{l}\text { Perpuataran } \\
\text { Aktiva }\end{array}$ & NPM & ROI & $\mathrm{ROE}$ & $\begin{array}{l}\text { Perpuataran } \\
\text { Aktiva }\end{array}$ & NPM & ROI & ROE \\
\hline 2014 & 0,072 & 0,006 & 0,014 & 0,006 & $-0,028$ & 0,015 & 0,005 & 0,008 \\
\hline 2015 & 0,033 & $0,062^{-}$ & $0,014^{-}$ & 0,009 & $-0,023$ & 0,075 & 0,011 & 0,005 \\
\hline 2016 & $-0,040$ & 0,032 & 0,001 & 0,008 & $-0,014$ & $0,013^{-}$ & 0,014 & $0,018^{-}$ \\
\hline
\end{tabular}


Berdasarkan tabel diatas, diketahui bahwa ROE selama empat tahun terakhir pada PT. AP I dan PT. AP II mengalami penurunan setiap tahunnya meskipun perusahaan menstabilkan nilai ROI terjadi penurunan pada net profit margin dan meningkatnya perputaran aktiva yang tidak mempengaruhi hasil ROE. ROI dari tahun 2013 dan 2014 dikatakan cukup baik karena cenderung mengalami peningkatan walaupun terjadi penurunan pada tahun-tahun selanjutnya. Hal tersebut ditunjukkan pada tabel yang mencerminkan penurunan ROI karena pengaruh nilai NPM dan perputaran aktiva disebabkan adanya pengaruh dari kemampuan perusahaan yang bisa berupa krisis, inflasi, fluktuasi nilai mata uang asing, serta meningkatnya beban pokok penjualan dan beban usaha yang lebih tinggi dibandingkan meningkatnya penjualan dan biaya operasional pada tahun tersebut sehingga berakibat penurunan pada laba bersih perusahaan.

$$
\text { Penurunan nilai NPM }
$$

merupakan salah satu indikator kinerja keuangan perusahaan, yang menunjukkan bahwa kondisi keuangan perusahaan kurang stabil dan memerikan penilaian bahwa perusahaan belum mampu menekan beban yang ada untuk mencapai laba yang optimal belum bisa terlaksana dengan baik. Sehingga pemanfaatan laba bersih atas penjualan dan pengembalian investasi belum maksimal.

Pencapaian ROE kedua perusahaan cukup baik. Semakin besar menurunnya pengganda ekuitas, maka semakin besar bagian aktiva yang dinilai oleh pemegang saham. Peningkatan ini menunjukkan bahwa tingkat penghasilan bersih yang diperoleh pemilik perusahaan atas modal yang diinvestasikan dalam perusahaan meningkat. Berarti perusahaan mampu mendayagunakan hutang untuk meningkatkan ROE. Keseluruhan hasil analisis $D u$ Pont System menunjukkan bahwa kinerja keuangan perusahaan selama periode 2013-2016 dalam kondisi yang baik walaupun terjadi penurunan.

1. Dari hasil analisis diatas menunjukkan bahwa perhitungan berdasarkan metode du pont system pada PT. AP I lebih rendah, ini terjadi karena rata-rata perputaran aktiva berfluktuasi, net profit margin setiap tahunnya menurun sedangkan pegganda ekuitas yang dihasilkan dari total aktiva dibagi dengan total ekuitas lebih besar dari PT. AP II. 
2. Pada PT. Angkasa Pura II perhitungan berdasarkan metode $d u$ pont system lebih unggul, ini karena net profit margin setiap tahun meningkat dan pengganda ekuitas menurun yang mengakibatkan nilai ROI dan ROE dalam metode tersebut masih lebih unggul atau lebih besar dari PT. Angkasa Pura I.

\section{Uji Beda Independent Sample} T-Test

Menurut Imam (2016:54) Uji beda t-test digunakan untuk menentukan apakah dua sampel yang tidak berhubungan memiliki nilai rata-rata yang berbeda. Uji t-test dilakukan dengan cara membandingkan perbedaan antara dua nilai rata-rata dengan standar error dari perbedaan rata-rata dua sampel. Syaratnya adalah data tersebut bertribusi normal dan homogen karena uji beda ini merupakan bagian dari uji statistik parametik. Datanya terdiri dari hasil matode financial ratio dan $d u$ pont system diantaranya kelompok PT. AP I dan PT. AP II.

Tabel

Hasil analisis uji beda independent t-test Group Statistics

\begin{tabular}{|l|l|r|r|r|r|}
\hline & Perusahaan & \multicolumn{1}{|c|}{ N } & \multicolumn{1}{c|}{ Mean } & \multicolumn{1}{c|}{$\begin{array}{c}\text { Std. } \\
\text { Deviation }\end{array}$} & \multicolumn{1}{c|}{$\begin{array}{c}\text { Std. Error } \\
\text { Mean }\end{array}$} \\
\hline $\begin{array}{l}\text { Financial ratio } \\
\text { dan du pont } \\
\text { system }\end{array}$ & PT. Angkasa Pura I & 60 & 44.6500 & 42.94254 & 5.54386 \\
\hline
\end{tabular}

Tabel

Hasil analisis uji beda independent t-test

\begin{tabular}{|c|c|c|c|c|c|c|c|c|c|}
\hline \multicolumn{10}{|c|}{ Independent Samples Test } \\
\hline & \multicolumn{2}{|c|}{$\begin{array}{l}\text { Levene's Test for } \\
\text { Equality of } \\
\text { Variances } \\
\end{array}$} & \multicolumn{7}{|c|}{ t-test for Equality of Means } \\
\hline & \multirow[b]{2}{*}{$\mathrm{F}$} & \multirow[b]{2}{*}{ Sig. } & \multirow[b]{2}{*}{$\mathrm{t}$} & \multirow[b]{2}{*}{$\mathrm{df}$} & \multirow{2}{*}{$\begin{array}{l}\text { Sig. }(2- \\
\text { tailed) }\end{array}$} & \multirow{2}{*}{$\begin{array}{c}\text { Mean } \\
\text { Difference }\end{array}$} & \multirow{2}{*}{$\begin{array}{l}\text { Std. Error } \\
\text { Difference }\end{array}$} & \multicolumn{2}{|c|}{$\begin{array}{l}95 \% \text { Confidence Interval of } \\
\text { the Difference }\end{array}$} \\
\hline & & & & & & & & Lower & Upper \\
\hline $\begin{array}{l}\text { Equal } \\
\text { variances } \\
\text { assumed }\end{array}$ & 14,774 &, 000 & $-2,194$ & 118 &, 030 & $-136,28333$ & 62,12224 & $-259,30229$ & $-13,26438$ \\
\hline $\begin{array}{l}\text { Equal } \\
\text { variances not } \\
\text { assumed }\end{array}$ & & & $-2,194$ & $\begin{array}{r}59,94 \\
7\end{array}$ &, 032 & $-136,28333$ & 62,12224 & $-260,54857$ & $-12,01809$ \\
\hline
\end{tabular}


Dalam tabel menjelaskan bahwa PT. AP I dengan jumlah data 60 dan rata-rata 44,65 dengan standar deviasi 42,9 dan standar eror rata-rata sebesar 5,5. Sedangkan pada PT. AP II dengan data sama sebanyak 60 dan rata-rata 180,9 dengan standar deviasi 479,28 dan standar eror rata-rata sebesar 61,88 . Menurut equal variances assumed nilai signifikansi 2-tailed sebesar 0,030 dimana data pengambilan keputusan jika nilai signifikansi 2-tailed lebih kecil dari 0,05 maka terdapat perbedaan yang signifikan antara hasil metode finnacial ratio dan $d u$ pont system pada PT. AP I dan PT. AP II.

\section{KESIMPULAN DAN SARAN}

\section{Kesimpulan}

Berdasarkan pengukuran kinerja keuangan melalui perhitungan financial ratio (rasio keuangan) dan $d u$ pont system yang telah dilakukan maka dapat ditarik kesimpulan sebagai berikut :

1. Kinerja keuangan Menurut Metode financial ratio menunjukkan kecenderungan meningkat. Rasio keuangan yang meliputi rasio likuiditas, solvabilitas, aktivitas, dan profitabilitas yang terdiri dari Current Ratio, Cash Ratio, Quick Ratio, Debt to Asset ratio, Debt to
Equity ratio, perputaran aktiva, perputaran total aktiva, Gross Profit Margin, NPM, ROI, dan $R O A$ secara keseluruhan hasil analisis rasio keuangan sudah dikatakan baik, meskipun masih terdapat beberapa rasio keuangan yang berfluktuasi. Namun dalam PT. AP I rasio perbandingan dalam kinerja keuangan lebih rendah dari PT. AP II ini terjadi karena pada PT. AP I jumlah laba, aktiva, hutang dan modal perusahaan lebih kecil dari PT. AP II. Namun pada PT. AP I lebih menjaga kestabilan kinerja keuangan ketimbang pada PT. AP II.

2. Kinerja keuangan berdasarkan metode $d u$ pont system untuk perperusahaan pada periode 20132016 adalah : PT. AP I merupakan perusahaan dengan nilai rata-rata sebesar 3\% yang berada dibawah dari PT. AP II yang sebesar 6\%. Namun kedua perusahan menunjukkan bahwa kinerja keuangan perusahaan cukup baik dan efisien karena tidak kurang dari $1 \%$.

3. Evaluasi perbandingan kinerja keuangan perusahaan pada PT. AP I dan PT. AP II dimana rata-rata perhitungan rasio yang berdasarkan metode financial ratio dan $d u$ pont 
system lebih unggul PT. AP II. Tetapi pada PT. AP II kurang jaga kestabilan dalam kinerja keuangan per tahunnya ini membuktikan bahwa belum tentu perusahaan dengan size besar bisa menjaga kestabilan aktiva dan total aktiva perusahaan. Pada PT. AP I lebih rendah rata-rata dari perhitungan PT. AP II namun, pada PT. AP I dapat menjaga kestabilan secara menyeluruh dalam kinerja keuangan pertahun selama empat tahun terakhir.

\section{Saran}

Berdasarkan kesimpulan yang diperoleh dari penelitian ini, maka penulis dapat memberikan saran-saran sebagai berikut.

1. Hasil dari perhitungan menggunakan rasio keuangan PT. AP I dan PT. AP II lebih banyak berfluktuasi atau belum stabil handaknya mendapat perhatian lebih dari pihak manajemen. Pihak manajemen seharusnya mengeluarkan kebijakan yang dapat membuat kegiatasn operasional perusahaan dapat berjalan lancar, efektif, dan efesien. Dana yang ada dalam perusahaan seharusnya dikelola secara baik dan benar agar perusahaan mampu menghasilkan laba yang optimal.

2. PT. AP I harus menjaga tingkat likuiditas dan solvabilitas agar perusahaan tidak mengalami kesulitan dalam membayar hutang yang jatuh tempo. Dengan meningkatnya kemampuan likuiditas, maka pihak kreditor tidak perlu khawatir dalam menanamkan dana, sedangkan pihak investor tidak perlu khawatir juga untuk berinvestasi pada PT. AP I.

3. Pada PT. AP II harus menjaga kestabilan rasio profitabilitasnya dengan melakukan efesiensi dan efektivitas usaha yang lebih terkontrol nantinya akan mempengaruhi kemampuan perusahaan untuk memperoleh laba dalam hubungannya dengan pengembalian investasi, ekuitas dan aktiva perusahaan.

\section{DAFTAR PUSTAKA}

Arief Sugiyono dan Edi Untung, 2016.

Panduan Praktis Dasar Analisa Laporan Keuangan. Jakarta: Grasindo.

Bambang Hermanto Mulyo Agung, 2015. Analisa Laporan Keuangan. Cetakan Keempat. Lentera Ilmu Cendekia, Jakarta. 
Budi Rudianto, 2012. Analisis Perbandingan Kinerja Keuangan PT. Telkom Tbk dengan PT. Indosat Tbk Periode 2005-2010). Jurnal Nasional: Universitas Bakrie Jakarta, ISSN 2089-3590.

Fransisca Yaningwati, 2015. Analisis Kinerja Keuangan Perusahaan (Perbandingan Penggunaan Analisis Rasio Keuangan dan Du Pont System) (Studi pada PT. Unilever Indonesia, Tbk dan Anak Perusahaan yang Terdaftar di Bursa Efek Indonesia Periode 2007-2013). Jurnal Administrasi Bisnis (JAB)|Vol. 25 No. 2 Agustus 2015

administrasibisnis.studentjou rnal.ub.ac.id

Hanafi, Mamduh. 2013. Manajemen Keuangan. Edisi Satu. Yogyakarta: BPFE

Harahap, Sofyan Syafri.2015. Analisis Kritis Atas Laporan Keuangan. Jakarta: Raja Gofindo Persada.

Hendrikus, 2014. Kamus Istilah Keuangan dan Akutansi. Jakarta, PT. Grasindo, anggota IKAPI.

Ikatan Akutansi Indonesia (IAI), 2015. Panduan Praktis Standar Akutansi Keuangan (PSAK), Jakarta: Salemba Empat.

Imam Ghozali. 2016. Aplikasi Analisis Multivariate dengan Program IBM SPSS 21. Cetakan ke delapan.
Semarang ISBN:

979.704.015.1- Undip.

Jumingan, 2015. Analisis Laporan Keuangan. Cetakakelima. Jakarta: Bumi Aksara

Kasmir, 2015. Analisis Laporan Keuangan. Cetakan Kedelapan. Jakarta: Rajawali Pers.

Laporan Tahunan Annual Report PT. Angkasa Pura 1 Tbk Tahun 2016 Diakses Bulan April 2017 dari (https://www.ap1.co.id)

Laporan Tahunan Annual Report PT. Angkasa Pura 2 Tbk Tahun 2016 Diakses Bulan April 2017 dari (www.angkasapura2.co.id/)

Munawir, 2010. Analisis Laporan Keuangan. Edisi Empat Cetakan Kelimabelas. Yogyakarta: Liberty

Munawir, 2016. Analisis Laporan Keuangan. Edisi Empat Cetakan Ketujuhbelas. Yogyakarta: Liberty

Mutiara Nur Rahma,2016. Analisis Laporan Keuangan dalam Menilai Kinerja Keuangan Industri Semen yang Terdaftar Di BEI (Studi Kasus PT Indocement Tunggal Prakarsa TBK). Jurnal Online Insan Akuntan, Vol.1, No.1, EISSN: 2528-0163.

Perpustakan Nasional RI. 2017. Analisis laporan keuangan. Teori, Aplikasi, dan Hasil Penelitian. Jakarta:Pustaka Baru Press. 
Poltak, Sinaga, 2014. Analisis Laporan Keuangan. Medan: MITRA Medan.

Ratnawaty Marginingsih, 2017. Penilaian Kinerja Perusahaan dengan Menggunakan Analisa Rasio Keuangan pada Perusahaan Telekomunikasi di Indonesia. Penilaian Kinerja Perusahaan dengan Menggunakan Analisa Rasio Keuangan pada Perusahaan Telekomunikasi di Indonesia. Cakrawala, Vol. VII, No. 1, Akademi Manajemen Keuangan BSI Jakarta, ISSN: 2579-3314.

Sugiyono, 2010. Metode Penelitian Bisnis. Cetakan Kelimabelas. Bandung. Alfabeta.

Sulistiyono, 2016 Pedoman Tehnis Penulisan Tugas Akhir Mahasiswa (Essay Guidelines)Fakultas Ekonomi.

Senja Priastuti. 2016. Analisis Perbandingan Laporan Keuangan untuk Menilai Kinerja Perusahaan Waralaba Makanan Cepat Saji. Jurnal Ilmu dan Riset Manajemen, Sekolah Tinggi Ilmu Ekonomi Indonesia (STIESIA) Surabaya, ISSN : 2461-0593

Toto Prihadi, 2013. Analisis Laporan Keuangan Teori dan Aplikasi. Cetakan ketiga. Jakarta: PPM. 